\title{
Microstructure and Wear Behavior of NbC-Reinforced Ni-Based Alloy Composite Coatings by Laser Cladding
}

\author{
Alex Pizzatto $^{a}$ (D), Moises Felipe Teixeira ${ }^{b}$, Alexsandro Rabelo ${ }^{b}$ (D), \\ Tiago Falcade ${ }^{c}$, Adriano Scheid ${ }^{*}$ (D)

\begin{abstract}
${ }^{a}$ Universidade Federal do Paraná, Programa de Pós-Graduação em Engenharia Mecânica (PGMEC), Av. Cel. Francisco H. dos Santos, 210, Curitiba, PR, Brasil.

${ }^{b}$ Instituto SENAI de Inovação (ISI-SENAI), R. Arno Waldemar Dohler, 308, Joinville, SC, Brasil

'Universidade Federal do Rio Grande do Sul (UFRGS), Programa de Pós-Graduação em Engenharia de Minas, Metalúrgica e de Materiais (PPGE3M), Departamento de Físico-Química, Av. Bento Gonçalves, 9500, Porto Alegre, RS, Brasil
\end{abstract}

Received: September 26, 2020; Revised: January 11, 2021; Accepted: February 16, 2021.

This work aims to evaluate the influence of laser power and reinforcement feeding rate on the microstructure, hardness, and wear behavior of $\mathrm{NbC}$-reinforced Hastelloy $\mathrm{C} 276^{\mathrm{TM}}$ alloy composite coatings. From a dual feeding system, one-step metal-matrix composite coatings were deposited with 10,30 , and $50 \%$ mass feeding of $\mathrm{NbC}$ powder with laser powers of 1.5 and $3.0 \mathrm{~kW}$. Coatings deposited with $1.5 \mathrm{~kW}$ and $30 \% \mathrm{NbC}$ showed some degree of porosity due to a combination of $\mathrm{NbC}$ feeding rate and melting pool temperature. Laser power and $\mathrm{NbC}$ feeding rate altered the melting efficiency and substrate burn-in shape, remarkably influencing the dilution. The composite microstructure was comprised of Ni- $\gamma$ (FCC) dendrites with interdendritic network carbide which, in turn, ranged from lamellar-like $\mathrm{M}_{6} \mathrm{C}$ to blocky-like conjugated $\mathrm{MC}-\mathrm{M}_{23} \mathrm{C}_{6}$ carbide. Primary petaloid-like $\mathrm{MC}[\mathrm{Nb}]$ carbide was formed from a $30 \%$ reinforcement rate on, whilst a considerable number of unmelted particles was observed for $50 \%$. The higher the reinforcement feeding rate, the higher the carbide fraction and better wear performance of low heat-input specimens. Synthesis with high heat-input sheds a light on the deleterious effect of the dilution and is not an option to enhance the wear performance.

Keywords: Metal-Matrix Composite, Nickel-based Superalloy, NbC Reinforcement, Microstructure, Wear.

\section{Introduction}

Metal-matrix composites (MMCs) have been draining attention because of the capability to join the ductility and toughness of a metal matrix to the high strength of ceramic materials. There are many different industrial areas interested in MMCs, for instance, aerospace and automotive, which are encouraged by emerging processes able to deliver uniform repeatable microstructures and properties ${ }^{1}$.

A great variety of welding processes have been considered to deposit, at the surface of the mechanical parts, protective layers to withstand severe and aggressive operating conditions. Given the complex degradation mechanisms, the components must have a good corrosion resistance concomitantly with good abrasive or adhesive wear performance. Thus, the processing of metal-matrix composites by laser cladding is inside a group of techniques available to produce MMCs with a highly attractive potential in the field ${ }^{2-4}$.

Many reinforcing phases may be added to metallic matrixes to form a composite coating, for example, TiC/Ni-based alloys ${ }^{5,6}$. Recently, some authors have studied $\mathrm{NbC}$ reinforcement of iron or cobalt-based alloys

"e-mail: scheid@ufpr.br synthesized in $\operatorname{situ}^{7-10}$. Pre-mixed powders were deposited by laser cladding either from a powder feeding system or in two-step with a preset powder layer on a substrate. These works have investigated the in situ carbide phase i.e., from the melting pool solidification, reinforcing the metal matrix to form a composite coating.

Nickel-chromium-molybdenum-tungsten alloy, commercially known as Hastelloy $\mathrm{C} 276^{\mathrm{TM}}$, is a high-molybdenum alloy with enhanced resistance to pitting. The solid solution hardening effect of tungsten and molybdenum enables high strength with no heat treatment ${ }^{11}$. Current welding studies pointed out the dilution rules on the above-mentioned alloy coatings properties, including the wear performance. When the alloy is deposited onto low carbon substrates, the dilution usually promotes a decrease in the wear performance, which is no longer a strong point of the alloy ${ }^{12-14}$. Otherwise, the deposition onto high-carbon substrates may lead to a significant increase in the coatings wear resistance ${ }^{13,14}$. Therefore, some works revealed the possibility of coating design by cladding with substrate material selection and dilution control ${ }^{12-18}$ while many others indicated, as a research opportunity, the processing of composite coatings by laser cladding ${ }^{2-10}$. The latter involves 
an even more intricate task because of the need to select and manage the clad alloy, reinforcement particle type, and its amount, substrate, and laser processing parameters ${ }^{19,20}$.

Laser cladding utilizes a laser source to melt an alloy powder or wire - coaxial and side laser cladding, respectively - onto a substrate as a way to form a protective layer with foreseeable and known properties ${ }^{19-23}$. Generally, the process set-up seeks for low dilution i.e., minimum molten substrate volume, which maintains the original chemical composition of feeding alloy holding, at the same time, metallurgical bonding between the coating and the substrate. Furthermost, the coating solidifies under high cooling rates and notably refined microstructures are verified when comparing with the conventional plasma spraying processes ${ }^{19-21}$.

The dilution and solidification cooling rates may lead to different phases in the microstructure of superalloys. Jiang et al. ${ }^{24}$ investigated the competitive formation of $\mathrm{M}_{2} \mathrm{C}$ and $\mathrm{M}_{6} \mathrm{C}$ in Ni-Mo-Cr superalloy and reported that the silicon content and cooling rate may influence the carbide type in as-cast microstructures. Shin et al. ${ }^{25}$ and Wieczerzak et al. ${ }^{26}$ studied different carbide types in Co- and Fe-based superalloys, respectively, and reported the wide solubility of most carbide i.e., the main carbide former sites in the crystal can be replaced by other metals in the composition. Moreover, Cao et al. ${ }^{27}$ investigated in situ formations of $\mathrm{NbC}$ in $\mathrm{Fe}$-based coatings and stated that niobium may react in the liquid phase at high temperature with carbon, originating primary $\mathrm{NbC}$ particles as petaloid octahedron structures.

Although previous works have studied $\mathrm{NbC}$ reinforcement of iron or cobalt-based alloys synthesized in situ ${ }^{7-10}$ either throughout one-step with pre-mixed powders or in two-step with a preset powder layer on a substrate, one-step composite coating synthesis adopting a dual-feeding system remains unexplored. Therefore, from a dual-feeding system, this work evaluated the effect of reinforcement feeding rate and laser power on the one-step NbC-reinforced Hastelloy C276 ${ }^{\mathrm{TM}}$ alloy metal-matrix composite coatings features. The analysis evolves focused on the microstructure characterization, hardness, and wear behavior of the coatings.

\section{Materials and Methods}

One-step metal-matrix composite coatings - NbC-reinforced Hastelloy $\mathrm{C} 276^{\mathrm{TM}}$ alloy - were deposited from a coaxial powder dual-feeding system on AISI 304L stainless steel plates substrate with a thickness of $12.0 \mathrm{~mm}$. Table 1 shows the chemical composition of the feeding materials and substrate. Table 2 presents a summary of the laser parameters adopted in a high-power diode laser (HPDL) PRECO ${ }^{\text {TM }}$ SL8600 deposition device.

The substrate was machined and sandblasted to a flat surface with a minimized amount of irregularities to obtain a uniform finishing condition and laser absorption. Figure 1 presents the typical feeding materials, including atomized Hastelloy C276 ${ }^{\mathrm{TM}}$ alloy (Hogänas powder) with particle size ranging from 53 to $150 \mu \mathrm{m}$ and niobium carbide powder (CBMM Niobium Company) ranging from 10 to $60 \mu \mathrm{m}$ particle size.

$\mathrm{NbC}$ powder was characterized by way of X-ray diffraction analysis with $\mathrm{K} \alpha-\mathrm{Cu}$ radiation from $2 \theta$ of 20 to $120^{\circ}$ with a scanning speed of $1^{\circ} \cdot \mathrm{min}^{-1}$, the angular step of $0.02^{\prime}$, and
Table 1. Feeding materials and substrate chemical composition (wt \%).

\begin{tabular}{|c|c|c|c|c|c|c|c|c|c|}
\hline \multicolumn{10}{|c|}{ Feeding Materials } \\
\hline \multirow{2}{*}{$\begin{array}{l}\text { Hastelloy } \\
\mathrm{C} 276^{\mathrm{TM}}\end{array}$} & $\mathbf{N i}$ & $\mathrm{Cr}$ & $\mathbf{W}$ & Mo & $\mathbf{C}$ & $\mathrm{Fe}$ & $\mathbf{V}$ & Si & Mn \\
\hline & Bal. & 15.4 & 4.5 & 15.9 & 0.10 & 3.1 & 0.6 & 0.6 & 1.1 \\
\hline \multirow{2}{*}{$\mathrm{NbC}$} & & $\mathbf{N b}$ & & & $\mathbf{C}$ & & & $\mathbf{F e}$ & \\
\hline & & 86.3 & & & 11.8 & & & 1.9 & \\
\hline \multicolumn{10}{|c|}{ Substrate } \\
\hline \multirow[t]{2}{*}{ AISI 304L } & $\mathbf{F e}$ & $\mathbf{C}$ & Mn & $\mathrm{Si}$ & $\mathbf{P}$ & $\mathbf{S}$ & $\mathrm{Cr}$ & $\mathbf{N i}$ & Mo \\
\hline & Bal. & 0.02 & 1.3 & 0.4 & 0.04 & 0.001 & 18.1 & 8.0 & 0.1 \\
\hline
\end{tabular}

Table 2. Summary of laser cladding parameters.

\begin{tabular}{lc}
\hline \multicolumn{1}{c}{ Feature } & Description \\
\hline Laser type & $\begin{array}{c}\text { High-Power Diode } \\
\text { Laser }(\mathrm{HPDL})\end{array}$ \\
\hline Travel speed $\left(\mathrm{mm} \cdot \mathrm{min}^{-1}\right)$ & 800 \\
\hline Focus distance $(\mathrm{mm})$ & 20 \\
\hline Laser spot size on the workpiece $(\phi, \mathrm{mm})$ & 5 \\
\hline Laser shield gas flow $\left(\mathrm{L} \cdot \mathrm{min}^{-1}\right)-$ Argon & 8 \\
\hline Powder feed rate $\left(\mathrm{g} \cdot \mathrm{min}^{-1}\right)$ & 25 \\
\hline Nozzle type & coaxial \\
\hline Nozzle angle $\left({ }^{\circ}\right)$ & 90 \\
\hline Laser power $(\mathrm{kW})$ & 1.5 and 3.0 \\
\hline NbC feeding rate $($ mass $\%)$ & 10,30 and 50 \\
\hline
\end{tabular}

the pattern analysis were carried out by Crystallographica Search-Match (CSM $\left.{ }^{\mathrm{TM}}\right)$ software, as seen in Figure 2.

Composite coatings were deposited as $80 \mathrm{~mm}$ in length single-beads, following the set-up parameters of preliminary studies (Table 2) ) $^{13,14}$. Visual inspection was performed to evaluate the presence of defects and the adhesion between coating and substrate. After discarding $10 \mathrm{~mm}$ at the bead extremities, macrographic specimens were prepared to evaluate the bead geometry following well-established methodology ${ }^{12,19}$ and involved measurements of wettability angle $(\Theta)$, bead width $(\mathrm{W})$, and clad height $(\mathrm{t})$. Dilution with the substrate was assessed by macrographic evaluation ${ }^{11,19}$.

Further analysis involved deposition efficiency defined as the ratio between the actual deposited mass-DM (g) and the fed mass - FM (g) for a constant time of deposition ${ }^{28}$. DM was calculated from the volume of the coating (from macrography) and considered the ponderate density of the materials - feeding and substrate - following the feeding rate set-up and dilution values. It is proper to mention that despite having a probable deviation between the proportion fed (set-up) and its actually melted and incorporated into the melting pool as well as the different dilution with the substrate, the ponderate density error may not be so high since the density of the Hastelloy $\mathrm{C} 276^{\mathrm{TM}}$ alloy $\left(8.87 \mathrm{~g} / \mathrm{cm}^{3}\right), \mathrm{NbC}$ carbide $\left(7.80 \mathrm{~g} / \mathrm{cm}^{3}\right)$ and AISI 304L stainless steel substrate $\left(8.0 \mathrm{~g} / \mathrm{cm}^{3}\right)$ are not pronouncedly different. Thus, we have proceeded with an approximate estimative of efficiency.

Metallographic specimens were prepared using automated grinding and polishing in an ATM ${ }^{\mathrm{TM}}$ German device. Microstructural analysis was performed by scanning electron microscopy - SEM (TESCANTM and ZEISS Supra ${ }^{\text {TM } 55 V P) ~}$ under backscattered electrons operational mode (BSE) in the transverse cross-section of the composite coatings. Also, energy dispersive spectrometry (EDS) was used to investigate 

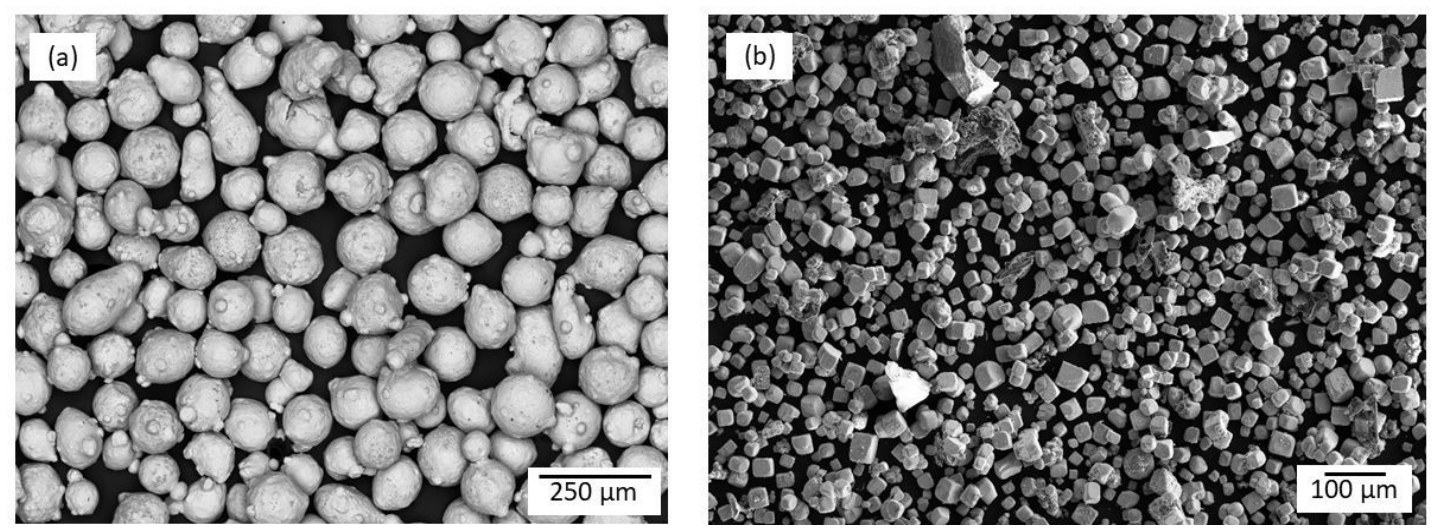

Figure 1. Typical feeding materials: Hastelloy C276 ${ }^{\mathrm{TM}}$ alloy (a) and Niobium Carbide (b).

NbC Powder Feeding Material

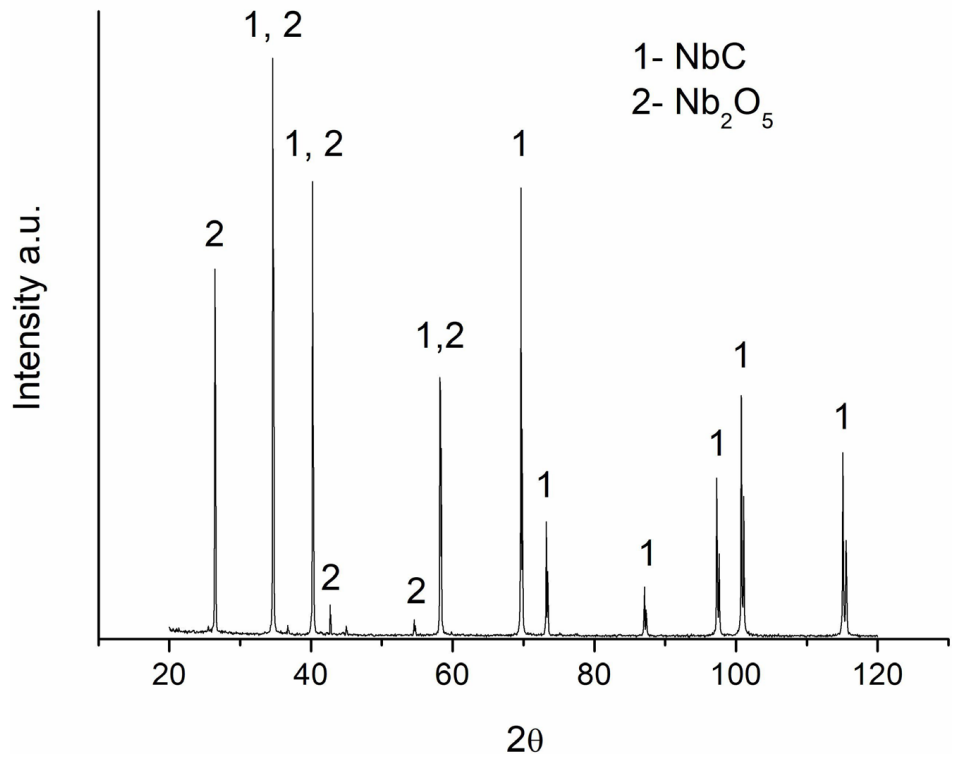

Figure 2. Typical X-ray patterns of $\mathrm{NbC}$ feeding powder.

the chemical composition of the phases formed (punctual analysis) and also the overall composition adopting an area of $0.25 \mathrm{~mm}^{2}$. Image $\mathrm{J}^{\mathrm{TM}}$ software ${ }^{29}$ was utilized to measure the carbide fraction by way of binary images under 250 and 5000X magnification. Phase evaluation followed the same earlier-mentioned procedure of X-ray diffraction analysis on the top surface of coatings.

After microstructural characterization, single beads were evaluated through Vickers hardness under $1 \mathrm{kgf}$ load in Shimadzu HMV G-21-XY equipment. Afterthought, ball-on-flat dry reciprocating sliding wear tests were performed sliding a $\mathrm{ZrO}_{2}$ sphere ( $6 \mathrm{~mm}$ diameter) on the top surface of composite coatings under $5 \mathrm{~N}$ load up to $120 \mathrm{~m}$ total sliding and $20 \mathrm{~mm} \cdot \mathrm{s}^{-1}$ maximum travel speeding a CSM Instruments $1-124^{\mathrm{TM}}$ model. Figure $3 \mathrm{a}$ and $\mathrm{b}$ present the schematic view of the single-bead and the top surface evaluated. Afterward, the worn tracks were analyzed by scanning electron microscopy and white light interferometry (Alicona ${ }^{\mathrm{TM}}$ Infinite Focus G5 machine), following the procedure described earlier ${ }^{14}$.
The wear rate was calculated as the worn volume $\left(\mathrm{mm}^{3}\right)$ divided by the load $(\mathrm{N})$ and the total sliding distance (m) following the previously reported method ${ }^{10}$.

\section{Results}

\subsection{Bead geometry, dilution, and deposition efficiency}

Figure 4 presents the macrographic analysis of the Hastelloy C276 ${ }^{\mathrm{TM}}$ alloy and composite coatings. Only the specimens deposited adopting $1.5 \mathrm{~kW}$ laser power and $30 \% \mathrm{NbC}$ feeding rate showed some degree of porosity.

Table 3 presents the single-bead geometry based on the cross-section images. The bead width showed a clear dependence on the laser power with higher values for $3.0 \mathrm{~kW}$ laser power. Initially, no obvious trend between the $\mathrm{NbC}$ feeding rate or laser power on the wettability angle and clad height was observed. 

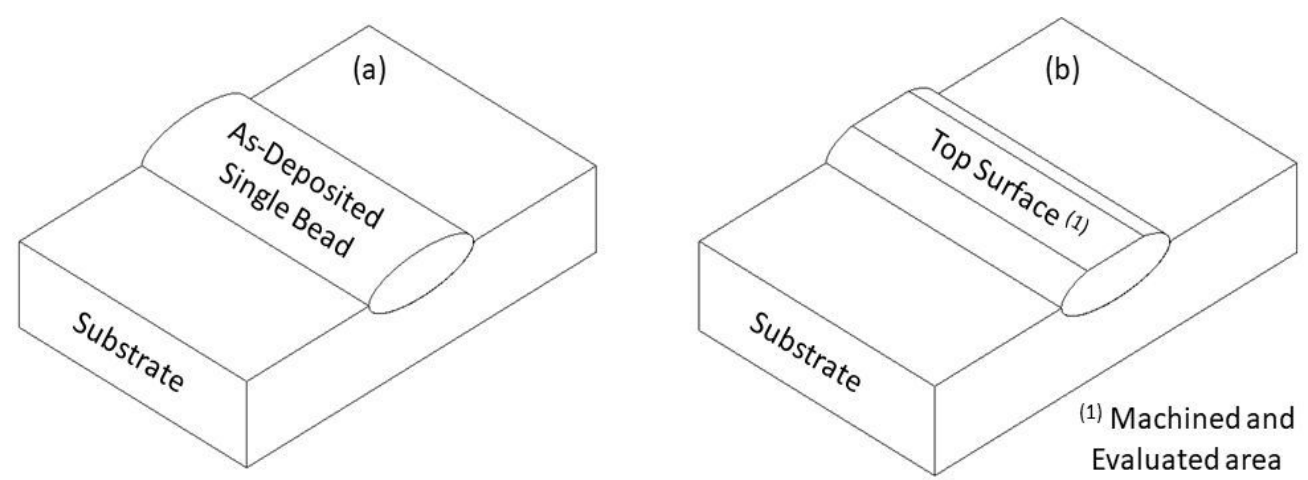

Figure 3. Schematic view of the single-bead: (a) as-deposited and (b) machined and evaluated top surface.
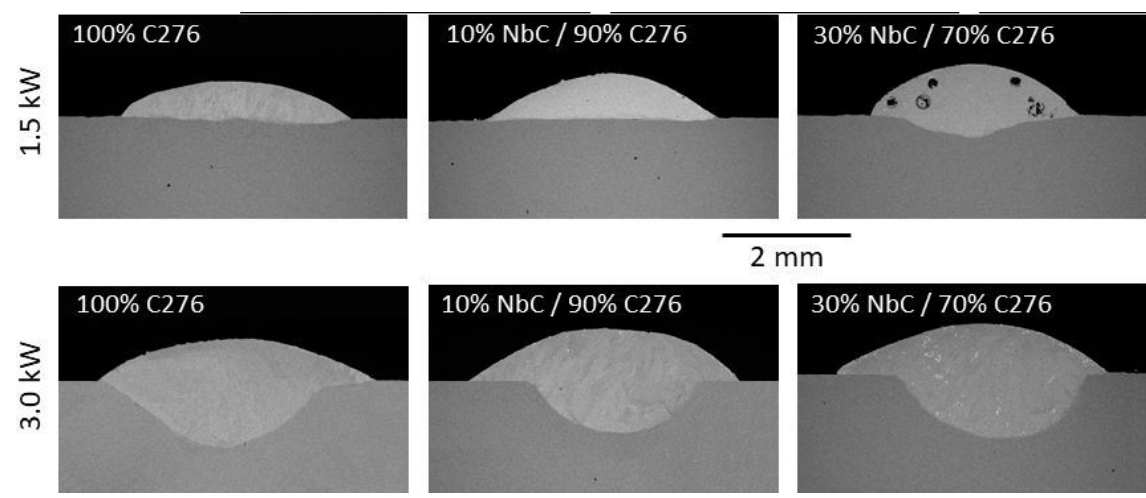

$2 \mathrm{~mm}$
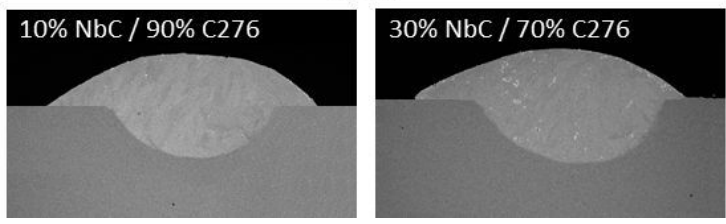
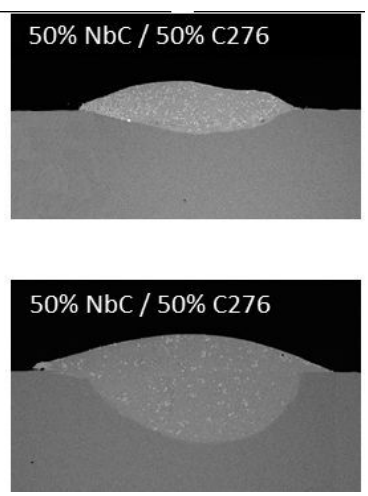

Figure 4. As deposited single-bead macrography of the coatings.

Table 3. Average bead geometry: wettability angle $(\Theta)$, bead width (BW), and clad height (t).

\begin{tabular}{ccccc}
\hline $\begin{array}{c}\text { Laser Power } \\
(\mathbf{k W})\end{array}$ & $\begin{array}{c}\text { NbC Feeding } \\
\text { Rate (\%) }\end{array}$ & $\Theta\left({ }^{\circ}\right)$ & $\begin{array}{c}\text { BW } \\
(\mathbf{m m})\end{array}$ & $\mathbf{t}(\mathbf{m m})$ \\
\hline \multirow{3}{*}{$\mathbf{1 . 5}$} & 0 & 35 & 3.6 & 0.60 \\
\cline { 2 - 5 } & 10 & 32 & 3.7 & 0.75 \\
\cline { 2 - 5 } & 30 & 50 & 3.3 & 0.85 \\
\hline \multirow{3}{*}{$\mathbf{3 . 0}$} & 50 & 32 & 3.5 & 0.50 \\
\cline { 2 - 5 } & 0 & 32 & 4.4 & 0.70 \\
\cline { 2 - 5 } & 10 & 39 & 4.3 & 0.90 \\
\cline { 2 - 5 } & 30 & 33 & 4.2 & 0.80 \\
\hline
\end{tabular}

Figure 5 shows the distribution of the dilution and deposition efficiency versus laser power and feeding rate where it is possible to observe greater dilution when higher laser power is adopted. Regardless of the laser power, a $10 \% \mathrm{NbC}$ feeding rate leads to a lower dilution, and from $30 \% \mathrm{NbC}$ on, higher dilution is observed. On the one hand, the highest efficiency observed for $10 \% \mathrm{NbC}$ led to higher deposited volume with a constant molten substrate, reducing the dilution. However, at a higher feeding rate, not only the reinforcement volume was reduced - due to efficiency decrease - but also the molten substrate was significantly increased, leading to increasing dilution.

\subsection{Microstructural evaluation}

Figure 6 and Figure 7 show the typical diffraction pattern obtained for the composite coatings. Those deposited with $1.5 \mathrm{~kW}$ presented Ni- $\gamma$ (FCC) solid solution and different carbide formation: $\mathrm{MC}$ [M: Nb, Mo], $\mathrm{M}_{6} \mathrm{C}$ [M: Fe, W, Mo], and $\mathrm{M}_{23} \mathrm{C}_{6}[\mathrm{M}: \mathrm{Cr}, \mathrm{Ni}, \mathrm{Fe}, \mathrm{Mo}, \mathrm{W}]$. Furthermost, processing with higher heat-input $(3.0 \mathrm{~kW})$ led to the same phases excepting the $\mathrm{M}_{6} \mathrm{C}[\mathrm{M}$ : Fe, W, Mo] carbide.

The microstructure was also evaluated from low to high magnification SEM images in the transverse cross-section of composite coatings. Even for the lower amount of $\mathrm{NbC}$ added $(10 \%)$, some $\mathrm{NbC}$ particles are not properly molten, as indicated by the arrows in the images, and the amount increases for higher feeding rates, reaching the most uniform distribution for $50 \% \mathrm{NbC}$, as shown in Figure 8 and Figure 9. Also, a certain quantity is accumulated on the top surface of coatings.

Besides the presence of unmelted NbC particles, it seems interesting now to evaluate the carbides formed from solidification, as shown in Figure 10 and Figure 11. Specimens reinforced with 10\% NbC (Figure 10b and Figure 11b) showed Ni- $\gamma$ (FCC) dendrites and interdendritic network carbides. Regardless of the laser power, from $30 \% \mathrm{NbC}$ on (Figure 10c and d and Figure 11c and d), composite coatings showed primary petaloid-like $\mathrm{MC}[\mathrm{M}: \mathrm{Nb}]$ carbide formed from the liquid. After $\mathrm{NbC}$ petals formation and metallic matrix dendritic growing, the interdendritic network carbide was formed.

Afterward, from high-resolution FEG-SEM images, it is possible to better describe the interdendritic network 


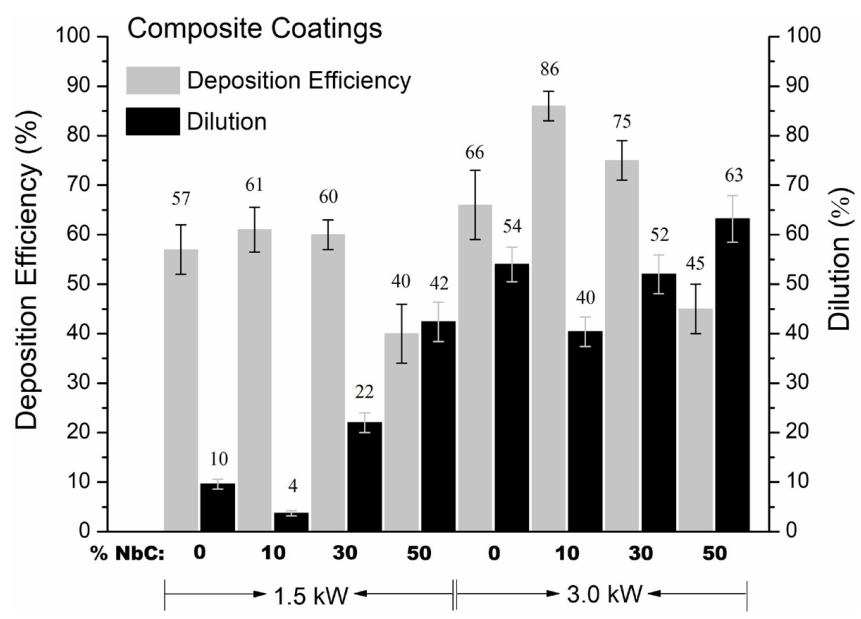

Figure 5. Average deposition efficiency and dilution.

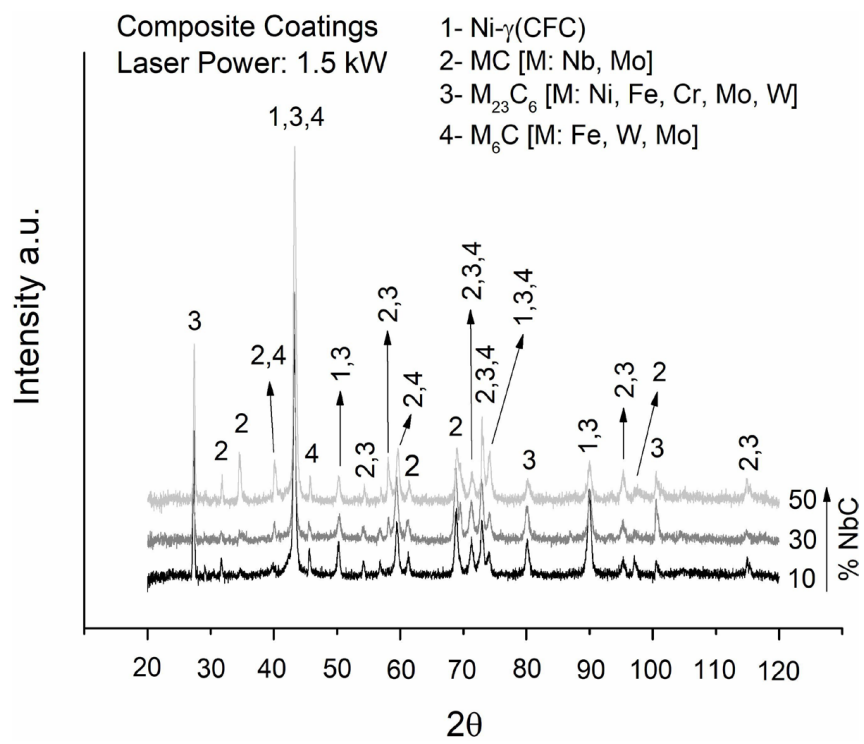

Figure 6. Typical X-ray diffraction pattern of composite coatings deposited applying $1.5 \mathrm{~kW}$ laser power.

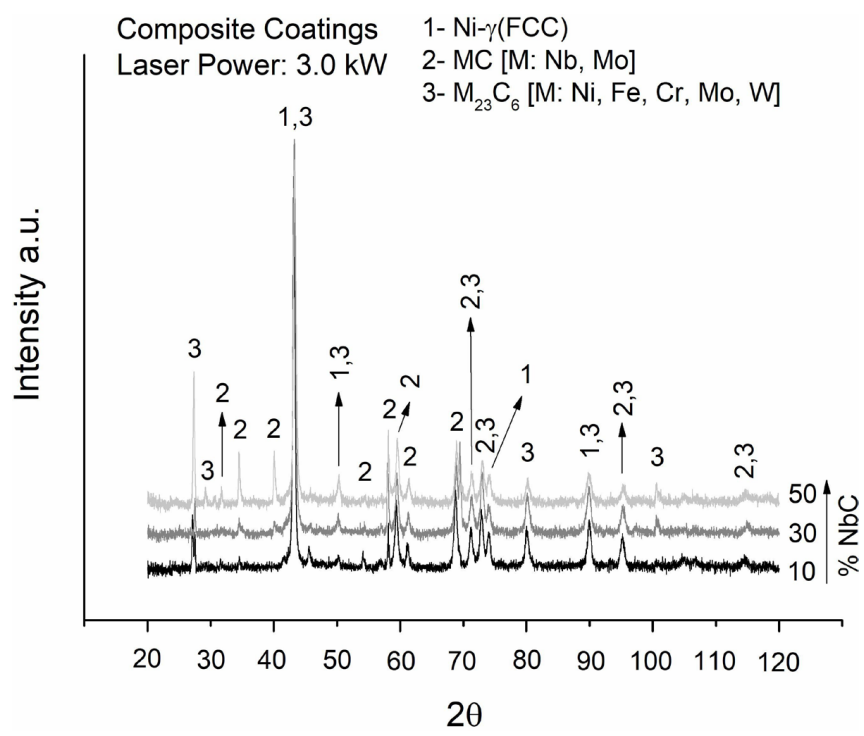

Figure 7. Typical X-ray diffraction pattern of composite coatings deposited adopting $3.0 \mathrm{~kW}$ laser power. 


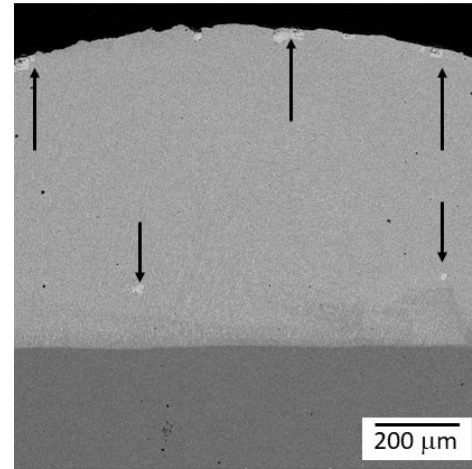

(a) $10 \% \mathrm{NbC}+90 \% \mathrm{C} 276$

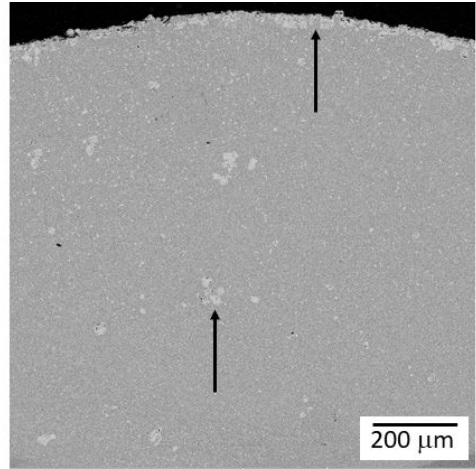

(b) $30 \% \mathrm{NbC}+70 \% \mathrm{C} 276$

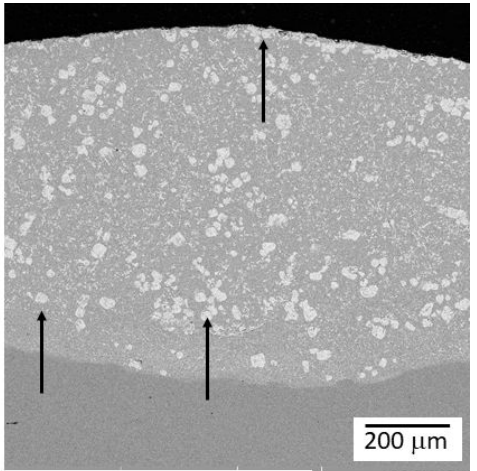

(c) $50 \% \mathrm{NbC}+50 \% \mathrm{C} 276$

Figure 8. Unmelted $\mathrm{NbC}$ carbide in the composite coatings deposited adopting $1.5 \mathrm{~kW}$ laser power.

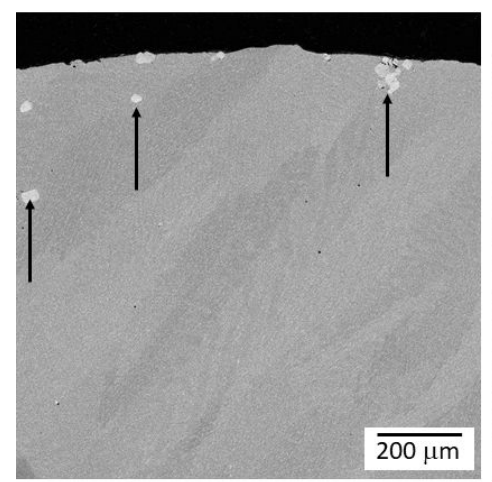

(a) $10 \% \mathrm{NbC}+90 \% \mathrm{C} 276$

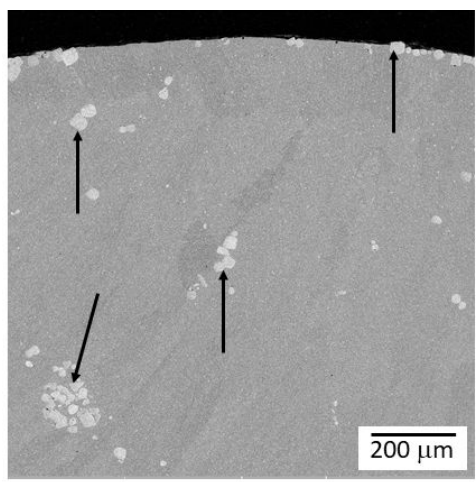

(b) $30 \% \mathrm{NbC}+70 \% \mathrm{C} 276$

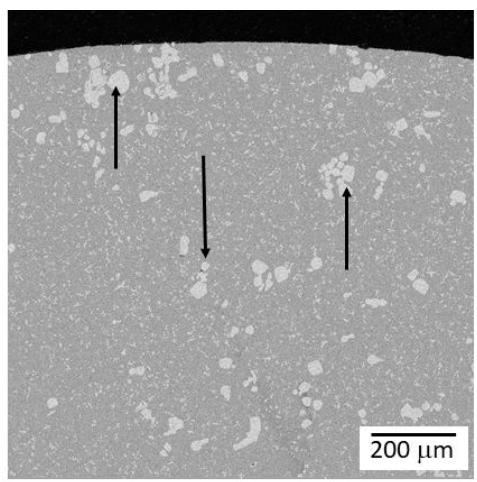

(c) $50 \% \mathrm{NbC}+50 \% \mathrm{C} 276$

Figure 9. Unmelted $\mathrm{NbC}$ carbide in the composite coatings deposited adopting $3.0 \mathrm{~kW}$ laser power.
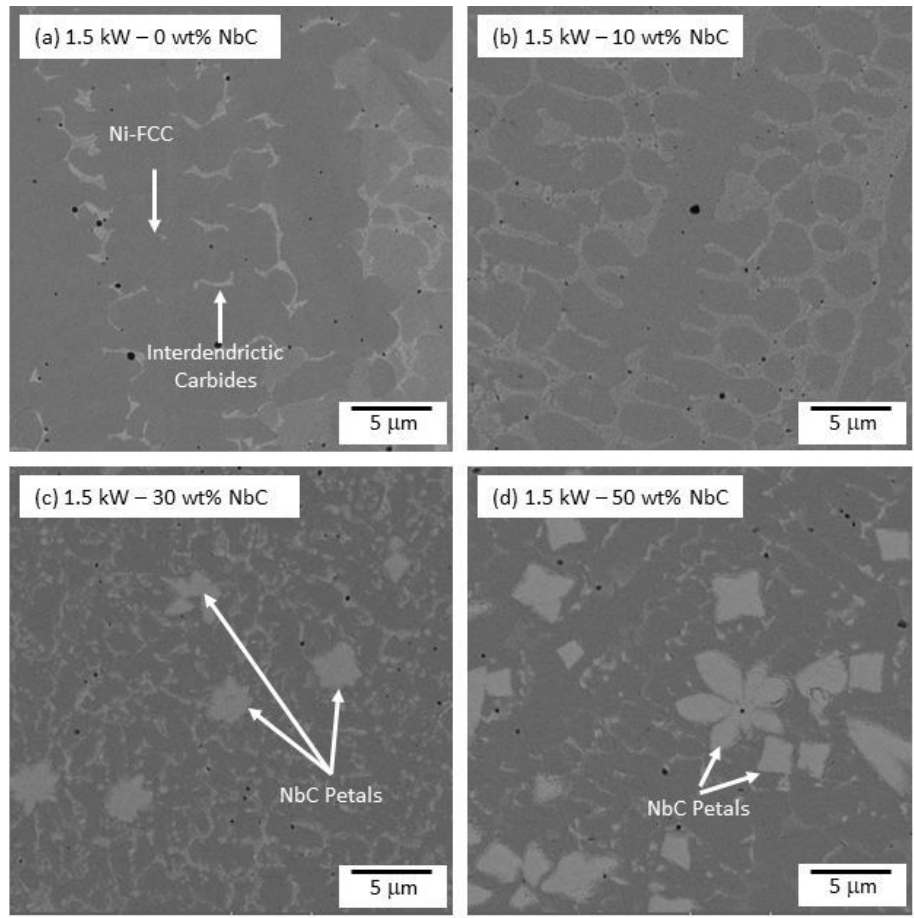

Figure 10. The microstructure of composite coatings deposited adopting $1.5 \mathrm{~kW}$ laser power. 

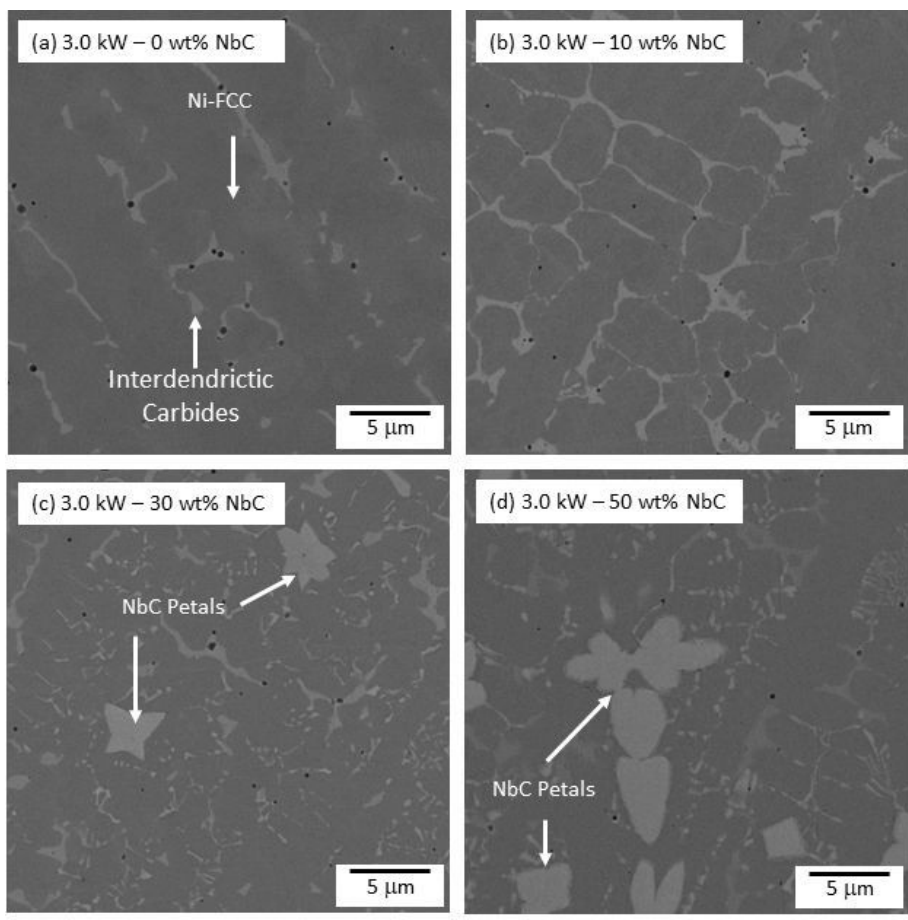

Figure 11. The microstructure of composite coatings deposited adopting $3.0 \mathrm{~kW}$ laser power.

carbide, as can be seen in Figure 12 to Figure 17. On the one hand, processing with $1.5 \mathrm{~kW}$ and $10 \% \mathrm{NbC}$ led to a prominent $\mathrm{M}_{6} \mathrm{C}$ lamellar-like interdendritic network carbide, also containing a blocky-like conjugated $\mathrm{MC}-\mathrm{M}_{23} \mathrm{C}_{6}$ type (see Figure 12a and b).

From the $30 \% \mathrm{NbC}$ feeding rate on, the fraction of blocky-like carbides increases as the feeding rate increases, as seen in Figure 13 and Figure 14.

Finally, coatings deposited with $3.0 \mathrm{~kW}$ laser power showed no $\mathrm{M}_{6} \mathrm{C}$ lamellar-like carbides and the analysis evolves basically with the blocky-like conjugated $\mathrm{MC}-\mathrm{M}_{23} \mathrm{C}_{6}$ type as can be seen in Figure 15, Figure 16, and Figure 17.

Table 4 shows the typical composition of the abovedescribed carbides, obtained by EDS punctual analysis. It is promptly seen that the unmelted carbide particles and the primary petaloid-like formed from solidification contain mainly niobium and carbon. Taking into account the interdendritic network carbides, MC carbide shows slightly higher molybdenum and carbon whilst $\mathrm{M}_{6} \mathrm{C}$ presents also silicon in its composition. Ultimately, the composition of $\mathrm{M}_{23} \mathrm{C}_{6}$ carbide encompasses higher chromium, iron, nickel, and molybdenum.

Considering the phase differences, the evaluation of the strengthening mechanisms seems to bring an interesting baseline on the properties and performance of composite coatings. Solid solution alloying was evaluated from EDS analysis (Table 5), carbide fraction (Table 6), and refinement degree (Table 7) were analyzed as follows. The higher the reinforcement feeding rate and laser power, the lower Mo, and $\mathrm{W}$ and higher $\mathrm{Nb}$ content. Chromium was not pronouncedly affected because of the substrate chromium content.

Generally, a higher $\mathrm{NbC}$ feeding rate induces a higher carbide fraction, independently from the laser power adopted.
Besides, the higher the feeding rate the lower the dendritic arm spacing.

\subsection{Hardness and wear behavior}

Higher hardness and lower wear rate were observed for composite coatings deposited with lower heat-input and higher $\mathrm{NbC}$ feeding rate, as shown in Figure 18 and Figure 19.

The evaluation of the wear tracks indicated the presence of darkened regions characterized as surface oxidation in the specimens deposited with no reinforcement, as shown in Figure 20. Also, the intensity of oxide formation seems to be reduced with the $\mathrm{NbC}$ addition, as seen in Figure 21.

\section{Discussion}

\subsection{Bead geometry, dilution, and deposition efficiency}

Considering welding defects, the coatings deposited with $1.5 \mathrm{~kW}$ laser power and 30\% NbC showed some degree of porosity (see Figure 4). According to Li et al. ${ }^{8}$, pores may be formed by the engulfed gas during powder feeding and rapid solidification. Beyond the carrying gas, one maybe not be discarded here the possibility of gas evolution $\left(\mathrm{CO} / \mathrm{CO}_{2}\right)$ due to the reaction between carbon and oxygen from feeding material and, thus, the $\mathrm{NbC}$ addition is a potential source of gas. Moreover, a higher burn-in shape was observed for higher $\mathrm{NbC}$ feeding rates, altering notably the melting pool temperature and, therefore, the gas trapping tendency. Hence, especially for $1.5 \mathrm{~kW}$ with $30 \% \mathrm{NbC}$, the increased feeding rate $(30 \% \mathrm{NbC})$ together with the rapid solidification probably led to a higher amount of porosity. Otherwise, for 10 and $50 \% \mathrm{NbC}$, porosity was not observed because of 

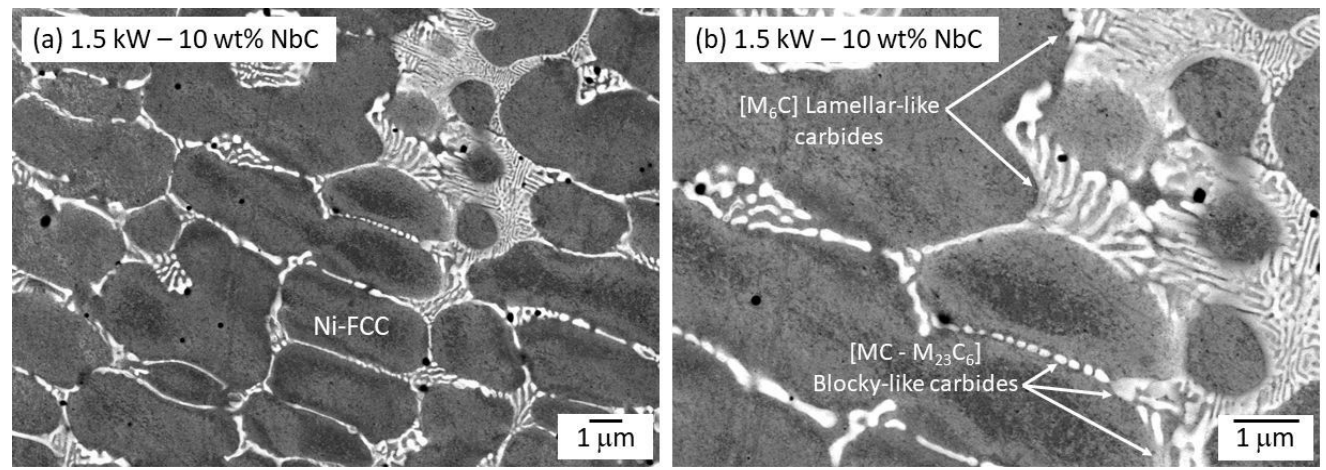

Figure 12. Interdendritic carbides formed in the coatings deposited with $1.5 \mathrm{~kW}$ laser power and $10 \% \mathrm{NbC}$ feeding rate.
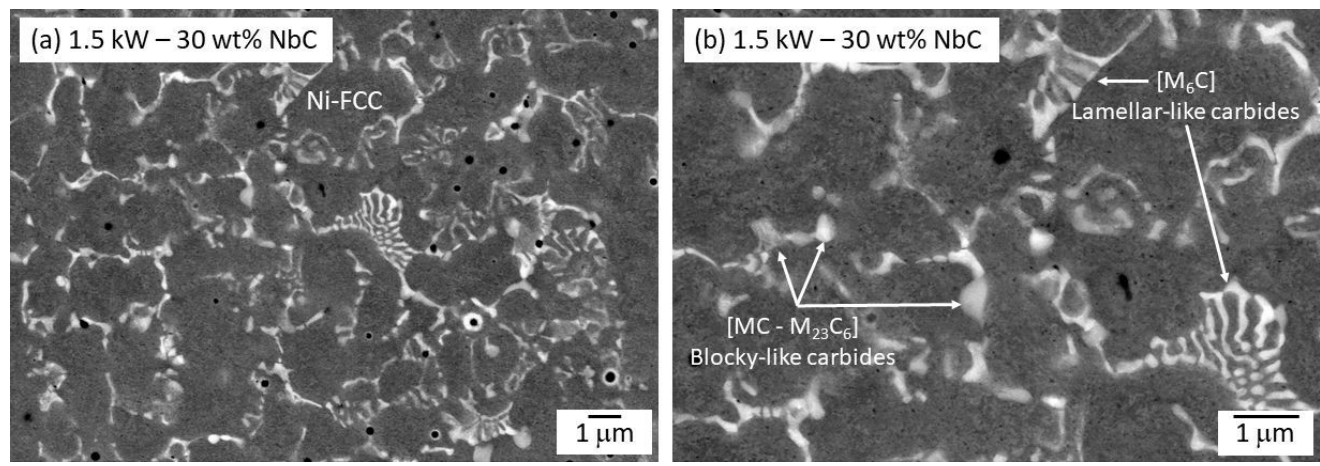

Figure 13. Interdendritic carbides formed in the coatings deposited with $1.5 \mathrm{~kW}$ laser power and $30 \% \mathrm{NbC}$ feeding rate.
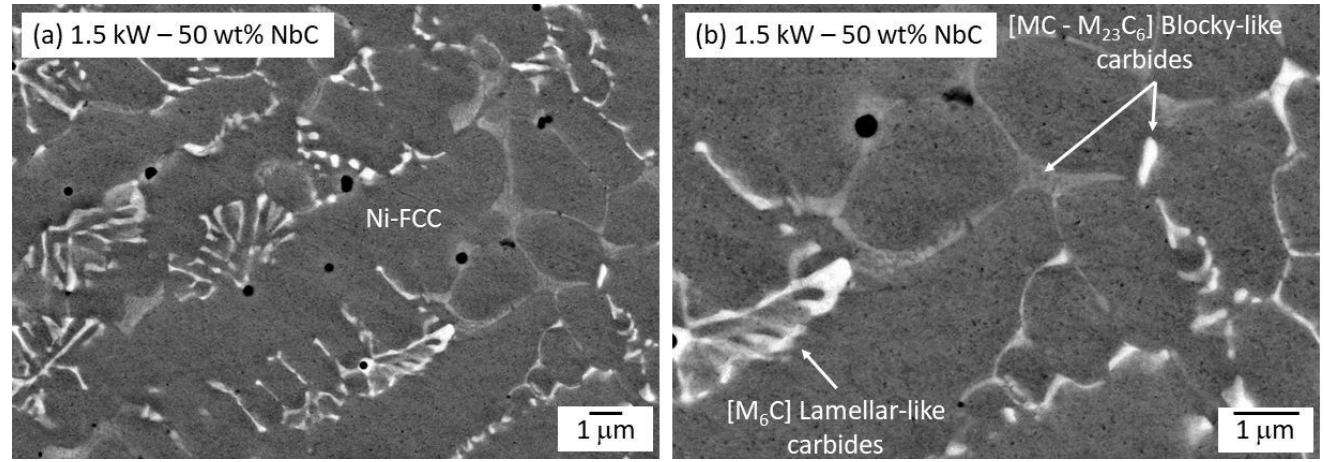

Figure 14. Interdendritic carbides formed in the coatings deposited with $1.5 \mathrm{~kW}$ laser power and $50 \% \mathrm{NbC}$ feeding rate.
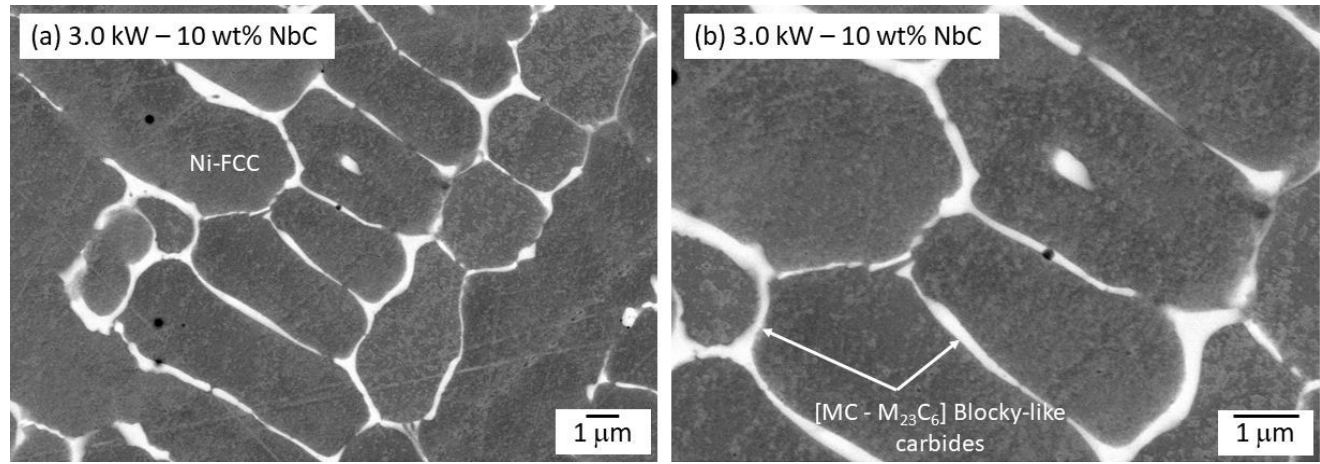

Figure 15. Interdendritic carbides formed in the coatings deposited applying $3.0 \mathrm{~kW}$ laser power and $10 \% \mathrm{NbC}$ feeding rate. 

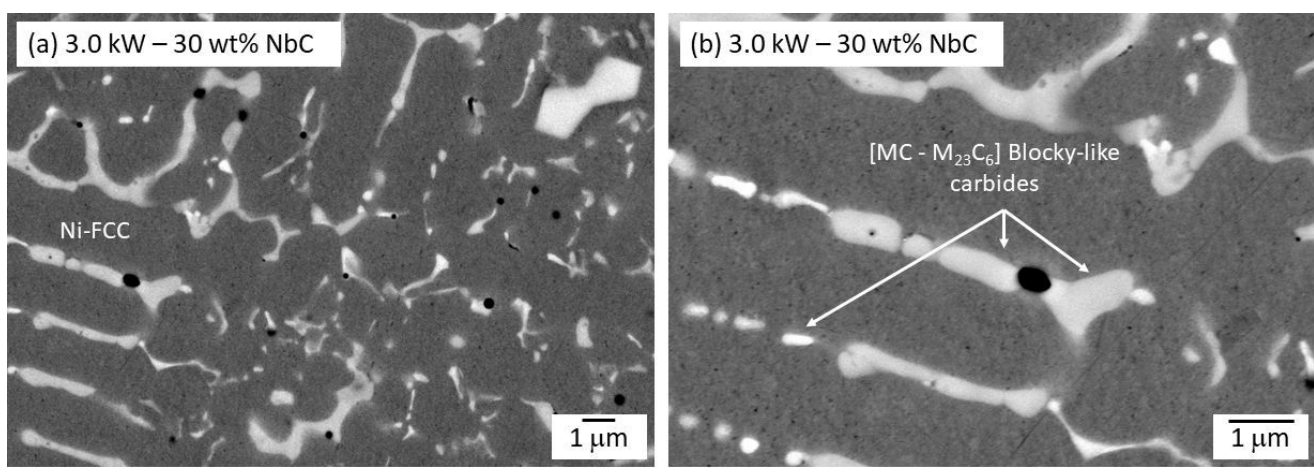

Figure 16. Interdendritic carbides formed in the coatings deposited with $3.0 \mathrm{~kW}$ laser power and $30 \% \mathrm{NbC}$ feeding rate.
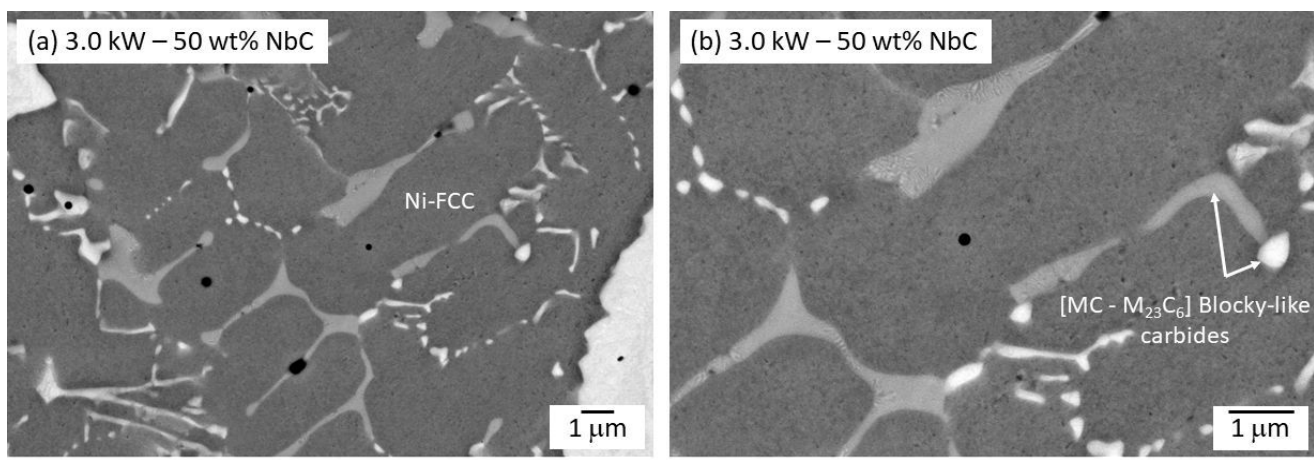

Figure 17. Interdendritic carbides formed in the coatings deposited with $3.0 \mathrm{~kW}$ laser power and $50 \% \mathrm{NbC}$ feeding rate.

Table 4. Typical EDS punctual analysis of the carbides formed.

\begin{tabular}{|c|c|c|c|c|c|c|c|c|c|}
\hline \multirow{2}{*}{$\begin{array}{c}\text { Laser power } \\
(\mathrm{kW})\end{array}$} & \multirow{2}{*}{ Punctual Region } & \multicolumn{8}{|c|}{ Chemical Composition (Wt\%) } \\
\hline & & $\mathbf{N i}$ & $\mathrm{Cr}$ & $\mathbf{F e}$ & Mo & $\mathbf{W}$ & $\mathbf{N b}$ & $\mathbf{C}$ & $\mathbf{S i}$ \\
\hline \multirow{5}{*}{1.5} & Unmelted $\mathrm{NbC}$ & --- & --- & --- & $\begin{array}{ll}-- \\
-1\end{array}$ & --- & 84.4 & 15.6 & --- \\
\hline & PPC & Bal. & 7.1 & 3.7 & 6.7 & 0.8 & 68.0 & 10.9 & --- \\
\hline & $\mathrm{INC}-\mathrm{M}_{6} \mathrm{C}$ & Bal. & 16.4 & 3.8 & 25.4 & 4.7 & 2.2 & 6.9 & 1.6 \\
\hline & $\mathrm{INC}-\mathrm{MC}$ & Bal. & 16.1 & 3.4 & 30.0 & 4.5 & 3.0 & 8.0 & --- \\
\hline & $\mathrm{INC}-\mathrm{M}_{23} \mathrm{C}_{6}$ & Bal. & 25.5 & 32.0 & 12.5 & 2.8 & 1.1 & 7.0 & --- \\
\hline \multirow{4}{*}{3.0} & Unmelted $\mathrm{NbC}$ & --- & --- & --- & $\begin{array}{ll}-- \\
--\end{array}$ & --- & 84.8 & 15.2 & --- \\
\hline & PPC & Bal. & 1.6 & 1.5 & 5.4 & 1.1 & 76.9 & 13.9 & --- \\
\hline & $\mathrm{INC}-\mathrm{MC}$ & Bal. & 22.6 & 20.7 & 24.8 & 4.3 & 1.6 & 11.4 & --- \\
\hline & $\mathrm{INC}-\mathrm{M}_{23} \mathrm{C}_{6}$ & Bal. & 27.6 & 34.0 & 15.3 & 2.6 & 1.9 & 6.5 & --- \\
\hline
\end{tabular}

PPC - Primary Petaloid Carbide, INC - $\mathrm{M}_{6} \mathrm{C}$ : Lamellar-like Interdendritic Network Carbide, INC - MC: White-Blocky Interdendritic Network Carbide, INC - $\mathrm{M}_{23} \mathrm{C}_{6}$ : Gray-Blocky Interdendritic Network Carbide

Table 5. Typical EDS measurements in a $0.25 \mathrm{~mm}^{2}$ area.

\begin{tabular}{|c|c|c|c|c|c|c|c|}
\hline \multirow{2}{*}{ kW } & \multirow{2}{*}{$\mathrm{NbC}(\%)$} & \multicolumn{6}{|c|}{ Chemical Composition - Wt\% } \\
\hline & & $\mathbf{N i}$ & $\mathrm{Cr}$ & $\mathrm{Fe}$ & Mo & $\mathbf{W}$ & $\mathbf{N b}$ \\
\hline \multirow{4}{*}{1.5} & 0 & Bal. & 15.4 & 8.6 & 16.0 & 4.9 & 0.0 \\
\hline & 10 & Bal. & 15.1 & 5.7 & 15.6 & 5.1 & 1.1 \\
\hline & 30 & Bal. & 13.6 & 17.8 & 10.6 & 3.6 & 18.1 \\
\hline & 50 & Bal. & 15.0 & 34.0 & 6.4 & 2.2 & 16.1 \\
\hline \multirow{4}{*}{3.0} & 0 & Bal. & 17.2 & 41.8 & 7.7 & 2.4 & 0.0 \\
\hline & 10 & Bal. & 15.5 & 31.5 & 10.0 & 3.2 & 1.4 \\
\hline & 30 & Bal. & 14.9 & 35.3 & 6.4 & 2.6 & 10.0 \\
\hline & 50 & Bal. & 14.1 & 41.0 & 4.2 & 1.4 & 21.1 \\
\hline
\end{tabular}


Table 6. Average carbide fraction of the composite coatings with the corresponding standard deviation of 5 measurements.

\begin{tabular}{rlrrrr}
\hline \multirow{2}{*}{$\mathbf{k}$ Carbide Type } & \multicolumn{4}{c}{ Reinforcement Feeding Rate } \\
\cline { 3 - 6 } & & $\mathbf{0 \% ~ N b C}$ & $\mathbf{1 0 \%} \mathbf{~ N b C}$ & $\mathbf{3 0 \%} \mathbf{~ N b C}$ & $\mathbf{5 0 \%}$ NbC \\
\hline \multirow{3}{*}{$\mathbf{1 . 5}$} & From Solidification & $5.5 \pm 0.4$ & $11.7 \pm 0.4$ & $15.5 \pm 0.9$ & $16.5 \pm 0.6$ \\
\cline { 2 - 6 } & Unmelted NbC & --- & $0.7 \pm 0.3$ & $1.6 \pm 0.2$ & $6.7 \pm 0.3$ \\
\cline { 2 - 6 } & Total & $\mathbf{5 . 5} \pm \mathbf{0 . 4}$ & $\mathbf{1 2 . 4} \pm \mathbf{0 . 7}$ & $\mathbf{1 7 . 1} \pm \mathbf{1 . 1}$ & $\mathbf{2 3 . 2} \pm \mathbf{0 . 9}$ \\
\hline \multirow{3}{*}{3.0} & From Solidification & $1.8 \pm 0.2$ & $7.0 \pm 0.5$ & $9.1 \pm 0.6$ & $14.1 \pm 1.0$ \\
\cline { 2 - 6 } & Unmelted NbC & --- & $0.5 \pm 0.1$ & $1.7 \pm 0.2$ & $5.4 \pm 0.3$ \\
\cline { 2 - 6 } & Total & $\mathbf{1 . 8} \pm \mathbf{0 . 2}$ & $\mathbf{7 . 5} \pm \mathbf{0 . 6}$ & $\mathbf{1 0 . 8} \pm \mathbf{0 . 8}$ & $\mathbf{1 9 . 5} \pm \mathbf{1 . 3}$ \\
\hline
\end{tabular}

Table 7. Average dendritic arm spacing (DAS) of the composite coatings with the corresponding standard deviation of 50 measurements.

\begin{tabular}{cccccc}
\hline \multirow{2}{*}{$\mathbf{k W}$} & $\begin{array}{c}\text { Refinement } \\
\text { Parameter }\end{array}$ & $\mathbf{0 \% ~ N b C}$ & $\mathbf{1 0 \%}$ NbC & $\mathbf{3 0 \%} \mathbf{~ N b C}$ & $\mathbf{5 0 \%}$ NbC \\
\cline { 3 - 6 } & DAS & $3.8 \pm 1.0$ & $2.4 \pm 0.5$ & $1.8 \pm 0.3$ & $1.5 \pm 0.2$ \\
\hline $\mathbf{1 . 5}$ & DAS & $4.3 \pm 0.5$ & $3.5 \pm 0.6$ & $2.3 \pm 0.8$ & $2.2 \pm 1.3$ \\
\hline $\mathbf{3 . 0}$ & & & &
\end{tabular}

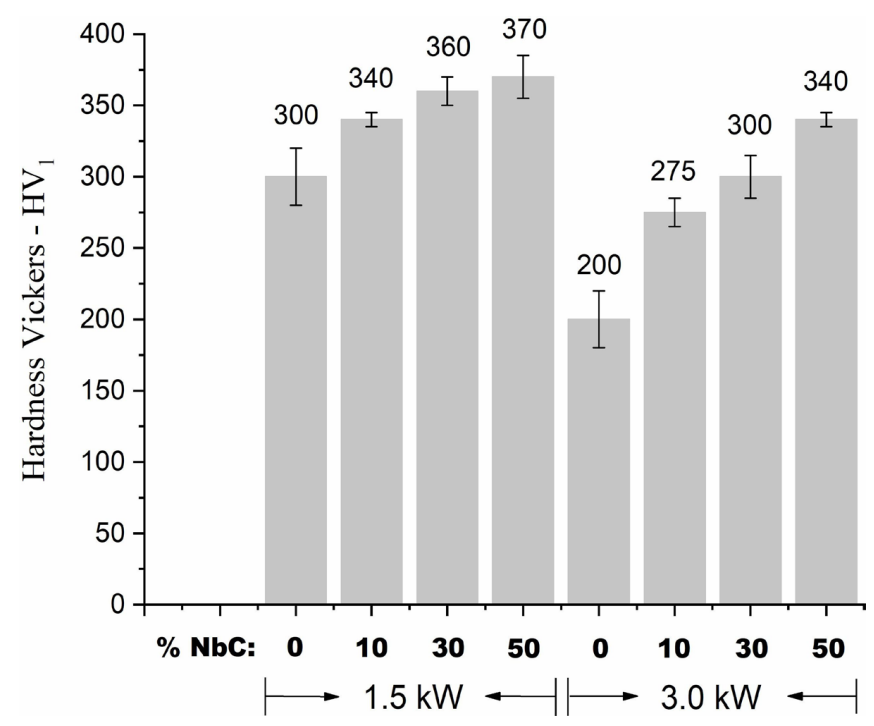

Figure 18. The hardness of composite coatings versus laser power and $\mathrm{NbC}$ feeding rate.

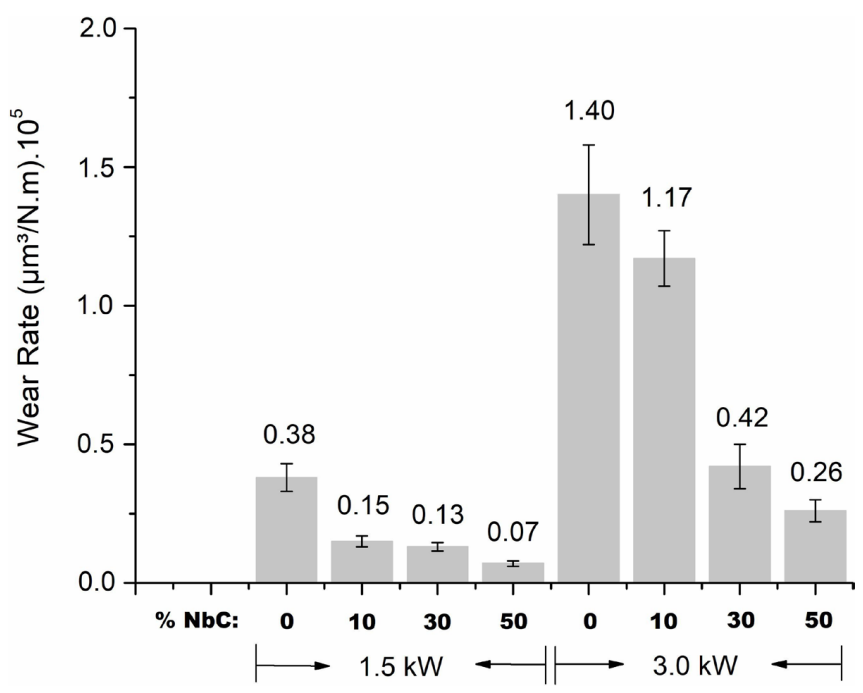

Figure 19. Wear rate of the composite coatings versus laser power and $\mathrm{NbC}$ feeding rate. 

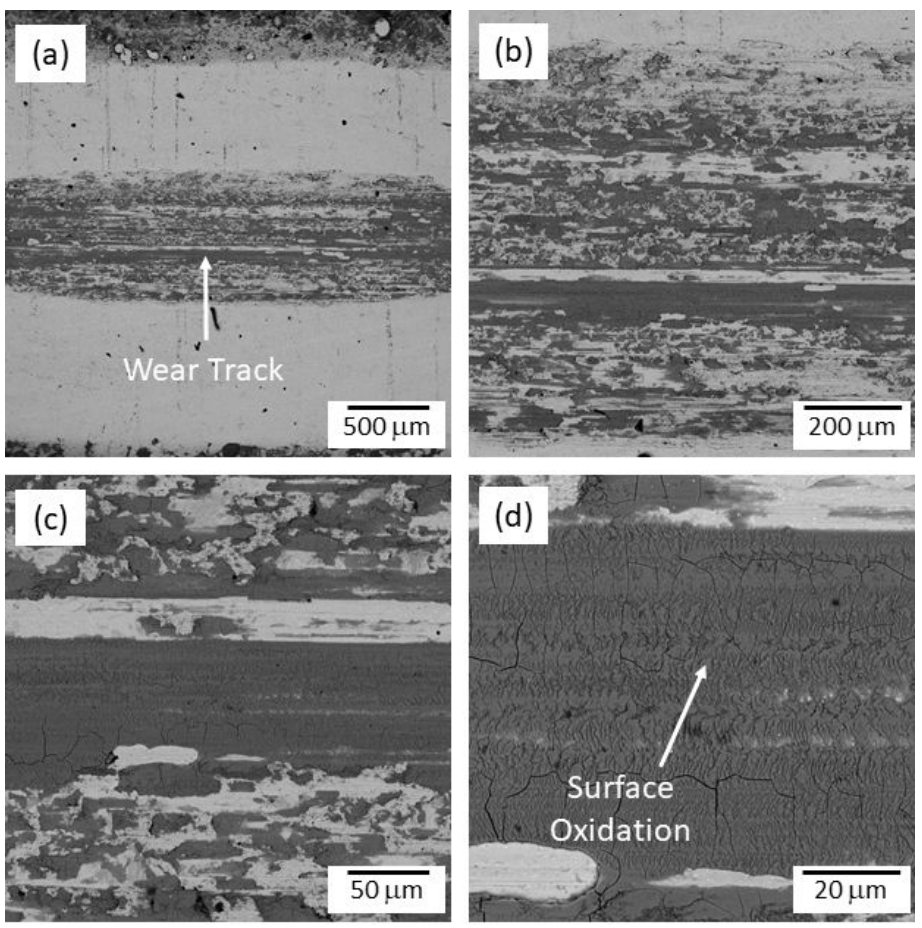

Figure 20. Wear track of the non-reinforced coating deposited with $1.5 \mathrm{~kW}$. Magnification increases from (a) to (d).
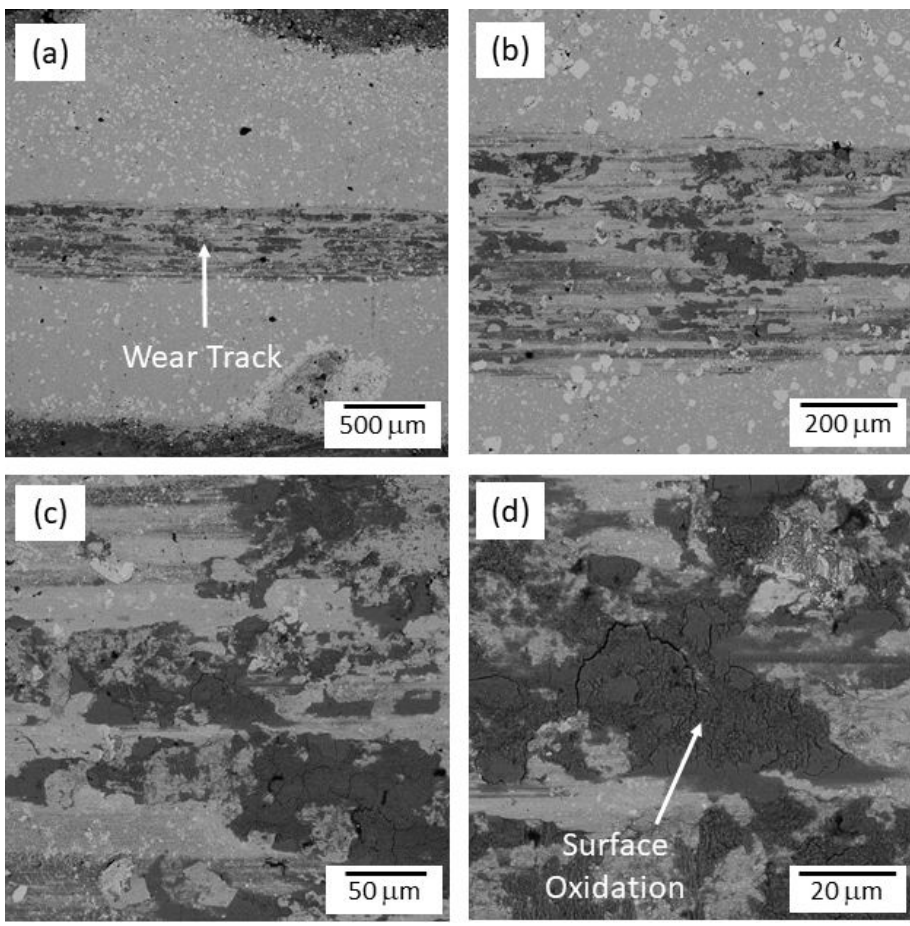

Figure 21. Wear track of the coating deposited with $1.5 \mathrm{~kW}$ and a $50 \% \mathrm{NbC}$ feeding rate. Magnification increases from (a) to (d).

either lower feeding rate or higher melting pool temperature which hindered the gas holding.

For the geometry (see Table 3 ), the bead width presented higher values for $3.0 \mathrm{~kW}$ and, since the laser power is increased, the bead width gets close to the nominal value of laser spot size, following the previous work ${ }^{14}$. Also, a higher clad height was observed for higher deposition efficiency (furtherly discussed in this section) following, with good confidence, the coatings molten volume, corroborating with the previous report ${ }^{22}$. However, no clear correlation between the $\mathrm{NbC}$ feeding rate or laser power and wettability angle was verified. Initially, it seems that the alloying of the metallic matrix with $\mathrm{NbC}$ induced a variable liquid surface tension of the composite coatings, resulting in an unpredictable 
wettability. However, at least three factors must be considered: the reinforcement feeding rate, deposition efficiency, and also dilution with the substrate.

Ibrahim, Mohamed, and Lavernia ${ }^{30}$ presented a review about particulate reinforced metal-matrix composites and pointed out that wettability may be measured through the solid-liquid contact angle $(\theta)$. The driving force for wetting depends on the solid-liquid interface energy and liquid surface tension, being influenced by many factors. At this rate, the discussion about dilution and deposition efficiency may shed a light on the above-mentioned intricate analysis.

Under the influence of the Gaussian laser energy distribution ${ }^{14,19,20}$, processing with $1.5 \mathrm{~kW}$ indicated a shallower molten substrate area with the most uniform burn-in shape (Figure 4). Thus, a higher dilution was measured for composite coatings deposited with high heat-input $(3.0 \mathrm{~kW})$, although a noteworthy increase was also identified as higher than $30 \% \mathrm{NbC}$ is added (Figure 5). Yaowei et al. ${ }^{31}$ reported that reactions with a high exothermic value of enthalpy along with the composite synthesis (conversion of oxide to carbide phase) contributed to a high dilution with the substrate. In the present study, the thermodynamic data ${ }^{32}$ showed niobium oxide $\left(\mathrm{Nb}_{2} \mathrm{O}_{5}\right)$ has lower Gibbs free energy when compared with niobium carbide $(\mathrm{NbC})$ and the expected conversion with the heat release should not occur.

Facing the variable powder mixtures and solidification process, it is reasonable to consider, at least, two different reasons for the above-mentioned effect of the $\mathrm{NbC}$ feeding rate on the dilution. From $30 \% \mathrm{NbC}$ on, the heat transfer from the laser beam to the high melting point $\mathrm{NbC}$ powder particles induced an increase in the melting pool temperature, notably evidenced by the larger burn-in shape (Figure 4). Also, it is plausible to suggest that the heat released from the solidification of the highly exothermic $\mathrm{NbC}$ primary phase may also have extended the time of the liquid phase.

Furthermore, the present investigation revealed the unmistakable influence of laser power (or heat-input) on the deposition efficiency which, in turn, was higher for $3.0 \mathrm{~kW}$ (Figure 5). Otherwise, when the $\mathrm{NbC}$ feeding rate is concerned, 10 and $30 \% \mathrm{NbC}$ induced a slight increase in deposition efficiency. At $50 \% \mathrm{NbC}$ it seems that the high melting point and the limited plasticity of the ceramic phase induced a more pronounced powder rebounding, lowering the efficiency.

Previous works ${ }^{22,23,28}$ have reported that efficiency is a drawback in powder feed laser cladding. It is related to the laser process parameters like laser power, powder feeding rate, feeding angle, travel speed, and so on. According to $\mathrm{Lee}^{28}$, for optimum deposition efficiency, the powder must stay in the laser beam as long as possible to be heated up and to became plastic when getting contact with the substrate surface. After that, the powder and substrate may be molten together with diminished rebounding.

From the discussion, understanding the complexity of the melting pool chemical composition is clearer. The unpredictable percentual of $\mathrm{NbC}$ added to the metal-matrix itself - due to the changeable deposition efficiency - and the distinct dilution with the substrate - altered concomitantly by the laser power and reinforcement feeding rate - helped to reveal how difficult is the task of bead geometry analysis in the synthesis of composite coatings.

\subsection{Microstructural evaluation}

Concerning the previous works ${ }^{12-14}$, the second phases formed in the Hastelloy $\mathrm{C} 276^{\mathrm{TM}}$ alloy deposited on the low conductivity stainless steel are expected, in this case, mainly gray blocky-like $\mathrm{M}_{23} \mathrm{C}_{6}[\mathrm{M}: \mathrm{Cr}]$ and white blocky-like $\mathrm{MC}$ [M: Mo] and, under certain conditions, also lamellarlike $\mathrm{M}_{6} \mathrm{C}[\mathrm{M}: \mathrm{Fe}, \mathrm{Mo}, \mathrm{W}]$ carbide. Otherwise, the different percentual of $\mathrm{NbC}$ added and the dilution trends reported in the previous section are rather important factors that govern the phase formation.

Shin et al. ${ }^{25}$ evaluated different carbide types in Co-based superalloy ( $\mathrm{M}_{6} \mathrm{C}, \mathrm{M}_{23} \mathrm{C}_{6}$, and others). The authors mentioned how intricate may be the phase identification through XRD analysis, basically due to the wide solubility of most carbide which, in turn, leads to variable lattice parameters. In this context, Wieczerzak, et al. ${ }^{26}$ investigated the carbide formation in $\mathrm{Fe}-\mathrm{Cr}-\mathrm{Mo}-\mathrm{C}$ alloy and reported that, in $\mathrm{M}_{23} \mathrm{C}_{6}$ [M: $\mathrm{Cr}$ ] carbide, $\mathrm{Cr}$ sites can be replaced by $\mathrm{Fe}$ and $\mathrm{Mo}$.

In this work, the diffraction pattern of composite coatings deposited with $1.5 \mathrm{~kW}$ (Figure 6) showed Ni- $\gamma$ (FCC) solid solution and different carbides: $\mathrm{MC}[\mathrm{M}: \mathrm{Nb}, \mathrm{Mo}]$, $\mathrm{M}_{6} \mathrm{C}[\mathrm{M}: \mathrm{Fe}, \mathrm{W}, \mathrm{Mo}]$ and $\mathrm{M}_{23} \mathrm{C}_{6}[\mathrm{M}: \mathrm{Cr}, \mathrm{Ni}, \mathrm{Fe}, \mathrm{Mo}, \mathrm{W}]$. Excepting $\mathrm{M}_{6} \mathrm{C}[\mathrm{M}: \mathrm{Fe}, \mathrm{W}, \mathrm{Mo}]$ carbide, the same phases were noticed in $3.0 \mathrm{~kW}$ specimens (Figure 7). The metallic elements replaced each other in the carbide formulae, following the above-referred authors ${ }^{25,26}$.

Regardless of the laser power, SEM evaluation revealed prevalent interdendritic network carbide for $10 \% \mathrm{NbC}$, interdendritic plus a low fraction of primary petals for $30 \% \mathrm{NbC}$, and, finally, interdendritic with a considerable amount of both primary petaloid-like and unmelted carbide for $50 \% \mathrm{NbC}$. Thus, further discussion evolves dealing with the microstructure formation and its features.

From $10 \% \mathrm{NbC}$ specimens, a noticeably higher fraction of interdendritic network carbide was observed in comparison to the non-reinforced alloy (Figure 10b and Figure 11b). As the columnar dendritic solidification starts from the Ni- $\gamma$ (FCC) metallic matrix, the carbide formers ( $\mathrm{Mo}, \mathrm{W}$, and $\mathrm{Nb}$ ) and carbon accumulate in interdendritic areas leading to the carbide network.

The detailed investigation of the carbide morphology showed that lamellar-like $\mathrm{M}_{6} \mathrm{C}$ was the main carbide in $10 \% \mathrm{NbC} / 1.5 \mathrm{~kW}$ specimens (Figure 12). The low dilution avoided the decrease in silicon and molybdenum content and the low heat-input led to a higher solidification cooling rate which hindered the segregation of carbon and molybdenum and dictated the $\mathrm{M}_{6} \mathrm{C}$ formation. The opposing effect was verified for $3.0 \mathrm{~kW}$ specimens, that is, the highest heat-input and dilution ( $>40 \%$ ) induced only blocky-like conjugated $\mathrm{MC}-\mathrm{M}_{23} \mathrm{C}_{6}$ carbide (Figure 15). Therefore, the results pointed out the rule of heat-input and dilution on the interdendritic carbide type and morphology. Jiang et al. ${ }^{24}$ investigated the competitive formation of $\mathrm{M}_{2} \mathrm{C}$ and $\mathrm{M}_{6} \mathrm{C}$ in $\mathrm{Ni}-\mathrm{Mo}-\mathrm{Cr}$ superalloy and reported that silicon induces a reduction in the Gibbs free energy of $\mathrm{M}_{6} \mathrm{C}$ carbide and can inhibit the $\mathrm{M}_{2} \mathrm{C}$ formation in as-cast microstructures. The authors also have argued that the formation of $\mathrm{M}_{2} \mathrm{C}$ needs more severe segregation to provide enough $\mathrm{Mo}$ and $\mathrm{C}$ when compared to $\mathrm{M}_{6} \mathrm{C}$ carbide. 
Specimens deposited with $30 \%$ NbC showed a low fraction of primary petaloid-like $\mathrm{MC}[\mathrm{M}: \mathrm{Nb}]$ formed at the beginning of the solidification. After petals formation and metallic matrix dendritic growing, the interdendritic carbide network was formed following the previous discussion. However, as niobium and carbon are partially consumed to form the primary $\mathrm{NbC}$ petals, the remaining liquid is depleted in these elements and, hence, the fraction of the interdendritic network is visibly diminished (Figure 10c and Figure 11c).

The interdendritic network carbide is markedly a mix comprised of lamellar-like $\mathrm{M}_{6} \mathrm{C}$ and blocky-like conjugated $\mathrm{MC}-\mathrm{M}_{23} \mathrm{C}_{6}$ carbide for $1.5 \mathrm{~kW}$ laser power (Figure 13). Higher dilution (23\%) reduced important elements to form $\mathrm{M}_{6} \mathrm{C}$ ( $\mathrm{Si}$ and $\mathrm{Mo}$ ) and higher chromium and niobium resulted in a larger fraction of blocky-like conjugated $\mathrm{MC}-\mathrm{M}_{23} \mathrm{C}_{6}$ type carbide. Lastly, since the dilution of $3.0 \mathrm{~kW}$ specimens exceeded $50 \%$, only blocky $\mathrm{MC}-\mathrm{M}_{23} \mathrm{C}_{6}$ type carbide was formed following the previous study ${ }^{24}$.

According to Cao et al. ${ }^{27}$ niobium may react in the liquid phase at high temperature with carbon, originating primary $\mathrm{NbC}$ particles. The authors characterized the in situ formation of $\mathrm{NbC}$ and proposed that it growing from the liquid phase may easier to occur at certain cubic crystalline directions with lower interfacial energy, resulting in petaloid octahedron structures. Chaidemenopoulos et al. ${ }^{33}$ experimentally studied the microstructure features of iron-based hardfacing materials and correlated them to thermodynamic predictions. In the case of hypereutectic composition containing niobium, the solidification starts from the primary $\mathrm{NbC}$ formation at high temperature (that case, $1931^{\circ} \mathrm{C}$ ), which was furtherly confirmed in the microstructural analysis.

Ultimately, a $50 \% \mathrm{NbC}$ feeding rate showed a considerable amount of unmelted $\mathrm{NbC}$ particles (Figure 8 and Figure 9) and a noticeable higher fraction of primary petals (Figure 10d and Figure 11d). Once again, since niobium and carbon are consumed to form the primary carbide petals and the remaining liquid is accordingly depleted in these elements, a lower fraction of the interdendritic network is observed. Also, the earlier mentioned competitive interdendritic carbide formation $\left(\mathrm{M}_{6} \mathrm{C} / \mathrm{MC}-\mathrm{M}_{23} \mathrm{C}_{6}\right)$ was observed for $1.5 \mathrm{~kW}$ coatings whilst a dominant gray-colored blocky-like $\left(\mathrm{M}_{23} \mathrm{C}_{6}\right)$ was formed in the highly diluted $3.0 \mathrm{~kW}$ condition. Typical composition of punctual EDS (see Table 4) on the abovedescribed carbides helped to identify the main elements, confirming the description claimed.

\subsection{Hardness and wear behavior}

Comparing the composites with different laser powers, it is clear that the superior hardness obtained for $1.5 \mathrm{~kW}$ is a result of the highest solid solution alloying and carbide fraction and more refined microstructures (Figure 18). Despite presenting contrary effects since the $\mathrm{NbC}$ feeding rate induces, at the same time, the increase of carbide fraction and higher dilution, the carbide formation is the prevalent effect on the hardness.

Concerning both heat-inputs, the reinforcement feeding rate and dilution are the influencing factors on the solid solution hardening of the Ni- $\gamma$ (FCC) metal matrix. The higher the reinforcement feeding rate and dilution the lower $\mathrm{Cr}$, Mo, and $\mathrm{W}$ and higher $\mathrm{Nb}$ content (see Table 5). Furthermost, a higher $\mathrm{NbC}$ feeding rate induces a higher carbide fraction (Table 6) and lower dendritic arm spacing (Table 7), the latter accounting for an even more well-distributed carbide network in the Ni- $\gamma$ (FCC) metal matrix.

From the wear evaluation, the most impressive results were observed for specimens processed with $1.5 \mathrm{~kW}$ laser power, reaching up to $82 \%$ reduction in the wear rate i.e., $0.38 \times 10^{5}$ to $0.07 \times 10^{5} \mu \mathrm{m}^{3} / \mathrm{N} . \mathrm{m}$ (Figure 19 ). The microstructure comprised of a high fraction of primary petaloid carbide, refined interdendritic network containing a mix of lamellarlike $\left(\mathrm{M}_{6} \mathrm{C}\right)$ plus conjugated blocky-like ( $\left.\mathrm{MC}-\mathrm{M}_{23} \mathrm{C}_{6}\right)$ carbides, and a considerable amount of unmelted carbide particles accounted for the lowest wear rate. Otherwise, the deleterious effect of dilution has nullified, to a certain degree, the benefit of $\mathrm{NbC}$ reinforcement on the wear rate of the specimens deposited with $3.0 \mathrm{~kW}$ laser power.

Pronouncedly oxidized wear tracks were observed in the specimens deposited with no reinforcement (see Figure 20). Otherwise, the $\mathrm{NbC}$ reinforcement leads to an improvement in the coating's performance due to the lower tribo-oxidation process (see $1.5 \mathrm{~kW}-50 \% \mathrm{NbC}$, Figure 21 ) without visible $\mathrm{NbC}$ particles agglomerated on the wear tracks (in the debris) as already reported in previous work ${ }^{34}$.

Mishra et al. ${ }^{35}$ studied the wear oxidation of Ni-base superalloys and stated that oxides may provide a protective layer, inhibiting the metal-metal contact or act as abrasives, accelerating the wear of the sliding surfaces. Previous reports ${ }^{13,14,35,36}$ reinforce the wear mechanism observed in the present work, with a successive growth and delamination of the oxide layer generated into the wear track due to the interaction between asperities.

From the results and discussion argued so far, one may look for composite coatings as a promising alternative to enhance the hardness and wear performance of the nickelbased alloy. Although the up-and-coming potential of composite processing, this work also pointed out a wellknown drawback of the powder feeding process, which is, the considerable powder loss. At the same time, the highest $\mathrm{NbC}$ feeding rate promoted an even more harmful effect on the deposition efficiency and the most attractive wear performance. This investigation has shown a demanding path for the research and development of wear-resistant materials through composite coatings synthesis.

\section{Conclusion}

This study evaluated the effect of laser power and $\mathrm{NbC}$ reinforcement feeding rate on the microstructure and properties of metal-matrix composite coatings deposited by laser cladding on AISI 304 L. The main conclusions can be drawn:

- From $30 \% \mathrm{NbC}$ on the reinforcement rate results in higher dilution and lower deposition efficiency. Thus, process control and its optimization is a complex task even more important in one-step powder feeding composite coatings.

- Composite coatings reinforcement phase was comprised of interdendritic network carbide for $10 \% \mathrm{NbC}$, primary petaloid-like plus network carbide for $30 \% \mathrm{NbC}$, and finally petaloid-like plus 
network carbide still containing unmelted particles for $50 \% \mathrm{NbC}$.

- The reinforcement feeding rate of $10 \%$ led to a higher fraction of the interdendritic network carbide. At higher rates, a gradual replacement of the interdendritic network by petaloid-like primary carbide ruled the formation of the phases from solidification.

- The composite carbide fraction did not encompass exactly the powder feed rate, due to the variable melting efficiency and dilution. However, a higher $\mathrm{NbC}$ feeding rate resulted in a higher carbide fraction and hardness than the non-reinforced alloy.

- The wear rate of coatings deposited with $1.5 \mathrm{~kW}$ laser power confirmed the expected benefit due to $\mathrm{NbC}$ addition, in this case, showing a wear performance up to $82 \%$ superior. The present study emphasized how attractive is to research the possibilities of superalloy reinforcement as metalmatrix composite coatings.

\section{Acknowledgments}

The authors thank SENAI Institute for Innovation (ISI Joinville) for the support of laser processing and characterization.

\section{References}

1. Chou TW, Kelly A, Okura A. Fibre-reinforced metal-matrix composites. Composites. 1985;16:187-206.

2. Man HC, Zhang S, Cheng FT, Yue TM. Microstructure and formation mechanism of in situ synthesized TiC/Ti surface MMC on Ti-6Al-4V by laser cladding. Scr Mater. 2001;44:2801-7. http://dx.doi.org/10.1016/S1359-6462(01)00977-0.

3. Emamian A, Corbin SF, Khajepour A. Effect of laser cladding process parameters on clad quality and in-situ formed microstructure of Fe-TiC composite coatings. Surf Coat Tech. 2010;205:200715. http://dx.doi.org/10.1016/j.surfcoat.2010.08.087.

4. Wang X, Zhang M, Qu S. Development and characterization of ( $\mathrm{Ti}, \mathrm{Mo}) \mathrm{C}$ carbides reinforced Fe-based surface composite coating produced by laser cladding. Opt Lasers Eng. 2010;48:8938. http://dx.doi.org/10.1016/j.optlaseng.2010.03.017.

5. Yang S, Zhong M, Liu W. TiC particulate composite coating produced in situ by laser cladding. Mater Sci Eng A. 2003;343:5762. http://dx.doi.org/10.1016/S0921-5093(02)00361-1.

6. Li Q, Lei TC, Chen WZ. Microstructural characterization of laser-clad Ti Cp-reinforced Ni-Cr-B-Si-C composite coatings on steel. Surf Coat Tech. 1999;114:278-84. http://dx.doi. org/10.1016/S0257-8972(99)00055-9.

7. Cao Y, Ren H, Hu R, Meng Q, Liu Q. In-situ formation behavior of NbC-reinforced Fe-based laser cladding coatings. Mater Lett. 2015;147:61-3. http://dx.doi.org/10.1016/j.matlet.2015.02.026.

8. Li Q, Lei Y, Fu H. Laser cladding in-situ NbC particle reinforced Fe-based composite coatings with rare earth oxide addition. Surf Coat Tech. 2014;239:102-7. http://dx.doi.org/10.1016/j. surfcoat.2013.11.026.

9. Sun S, Fu H, Ping X, Lin J, Lei Y, Wu W, et al. Reinforcing behavior and microstructure evolution of $\mathrm{Nb} \mathrm{C}$ in laser cladded Ni45 coating. Appl Surf Sci. 2018;455:160-70. http://dx.doi. org/10.1016/j.apsusc.2018.05.199.

10. Chen Z, Yan H, Zhang P, Yu Z, Lu Q, Guo J. Microstructural evolution and wear behaviors of laser-clad Stellite $6 / \mathrm{NbC} / \mathrm{h}-\mathrm{BN}$ self-lubricating coatings. Surf Coat Tech. 2019;372:218-28. http://dx.doi.org/10.1016/j.surfcoat.2019.04.083.
11. Mankins WL, Lamb S. Nickel and nickel alloys. In: ASM International. Properties and selection: nonferrous alloys and special-purposed materials. Ohio: Materials Park; 1990. p. 1363-403.

12. Ferreira LS, Graf K, Scheid A. Microstructure and properties of Nickel-based C276 Alloy Coatings by PTA on AISI 316L and API 5L X70 steel substrates. Mater Res. 2015;18:212-21. http://dx.doi.org/10.1590/1516-1439.332914.

13. Rivero LEHS. Avaliação de revestimentos de superliga Hastelloy ${ }^{\circledR}$ C276 depositados a laser sobre diferentes substratos [dissertação]. Curitiba: Universidade Federal do Paraná; 2019 [cited 2018 Mar 20]. Available from: www.prppg.ufpr.br/pgmec/ wp-content/uploads/2020/01/lubar.pdf

14. Rivero LEHS, Pizzatto A, Teixeira MF, Rabelo A, Falcade T, Scheid A. Effect of laser power and substrate on the hastelloy C276TM coatings features deposited by laser cladding. Mater Res. 2020;25:1-11. http://dx.doi.org/10.1590/1980-5373MR-2020-0067.

15. Fernandes F, Cavaleiro A, Loureiro A. Oxidation behavior of Ni-based coatings deposited by PTA on gray cast iron. Surf Coat Tech. 2012;207:96-203. http://dx.doi.org/10.1016/j. surfcoat.2012.06.070.

16. Graf K, Tetzlaff U, Souza GB, Scheid A. Effect of dilution on the microstructure and properties of CoCrMoSi alloy coatings processed on high-carbon substrate. Mater Res. 2019;22:1-7. http://dx.doi.org/10.1590/1980-5373-MR-2018-0502.

17. Antoszczyszyn TJ, Paes RMG, Oliveira ASCM, Scheid A. Impact of dilution on the microstructure and properties of Nibased 625 alloy coatings. Soldag Insp. 2014;19:134-44. http:// dx.doi.org/10.1590/0104-9224/SI1902.05.

18. Paes RMG, Martinazzi D, Falcade T, Scheid A. Effect of bead overlapping on the microstructure and mechanical properties of CoCrWC alloy coatings. Mater Res. 2018;21:1-7. http:// dx.doi.org/10.1590/1980-5373-MR-2018-0274.

19. Toyserkani E, Khajepour A, Corbin S. Laser cladding. Washington: CRC Press; 2005. p. 179-224.

20. Goodarzi DM, Pekkarinen J, Salminen A. Effect of process parameters in laser cladding on substrate melted areas and the substrate melted shape. J Laser Appl. 2015;27:1-9. http:// dx.doi.org/10.2351/1.4906376.

21. Zhong M, Liu W. Laser surface cladding: the state of the art and challenges. Proceedings of the Institution of Mechanical Engineers, Part C: Journal of Mechanical Engineering Science. 2010;224(5):1-20. http://dx.doi.org/10.1243/09544062JMES1782.

22. Haldar B, Saha P. Identifying defects and problems in laser cladding and suggestions of some remedies for the same. Mater. Today Proc. 2018;5:13090-101. http://dx.doi.org/10.1016/j. matpr.2018.02.297.

23. Mahamood RM. Laser metal deposition process of metals, alloy, and composite materials, Switzerland: Springer International Publishing; 2018.

24. Jiang L, Zhang W, Xu Z, Huang H, Ye X, Leng B, et al. ${ }_{2} \mathrm{C}$ and $\mathrm{M}_{6} \mathrm{C}$ carbide precipitation in Ni-Mo-Cr based superalloys containing silicon. Mater Des. 2016;112:300-8. http://dx.doi. org/10.1016/j.matdes.2016.09.075.

25. Shin J, Doh J, Yoon J, Lee D, Kim J. Effect of molybdenum on the microstructure and wear resistance of cobalt-base Stellite hardfacing alloys. Surf Coat Tech. 2003;166:117-26. http:// dx.doi.org/10.1016/S0257-8972(02)00853-8.

26. Wieczerzak K, Bala P, Stepien M, Cios G, Koziel T. Formation of eutectic carbides in $\mathrm{Fe}-\mathrm{Cr}-\mathrm{Mo}-\mathrm{C}$ alloy during nonequilibrium crystallization. Mater Des. 2016;94:61-8. http:// dx.doi.org/10.1016/j.matdes.2016.01.028.

27. Cao Y, Zhi S, Gao Q, Tian X, Geng T, Guan X, et al. Formation behavior of in-situ $\mathrm{NbC}$ in Fe-based laser cladding coatings. Mater Charact. 2016;119:159-65. http://dx.doi.org/10.1016/j. matchar.2016.08.005

28. Lee H. Effects of the cladding parameters on the deposition efficiency in pulsed Nd: YAG laser cladding. J Mater Process 
Technol. 2008;202:321-7. http://dx.doi.org/10.1016/j. jmatprotec.2007.09.024.

29. Rasband WS. Image J [Internet]. Bethesda: U. S. National Institutes of Health; 1997-2015 [cited 2018 Mar 20]. Available from: http://imagej.nih.gov/ij/

30. Ibrahim IA, Mohamed FA, Lavernia EJ. Particulate reinforced metal matrix composites - a review. J Mater Sci. 1991;26:11371156. http://dx.doi.org/10.1007/BF00544448.

31. Yaowei Y, Wei F, Xiang Z, Qilin D, Jianguo Y. In-situ synthesis of WC/TaC reinforced Nickel-based composite alloy coating by laser cladding. Rare Met Mater Eng. 2017;46:3176-81. http:// dx.doi.org/10.1016/S1875-5372(18)30024-9.

32. Barin I. Thermochemical Data of Pure Substances. Germany: Wiley-VCH Verlag GmbH; 1995. p. 1163-1175.
33. Chaidemenopoulos NG, Psyllaki PP, Pavlidou E, Vourlias G. Aspects on carbides transformations of Fe-based hardfacing deposits. Surf Coat Tech. 2019;357:651-61. http://dx.doi. org/10.1016/j.surfcoat.2018.10.061.

34. Woydt M, Mohrbacher H. Friction and wear of binder-less niobium carbide. Wear. 2013;306:126-30. http://dx.doi. org/10.1016/j.wear.2013.07.013.

35. Mishra SB, Chandra K, Prakash S. Dry sliding wear behavior of nickel-, iron- and cobalt-based superalloys. Tribology. 2013;7:1228. http://dx.doi.org/10.1179/1751584X13Y.0000000038.

36. Navas C, Cadenas M, Cuetos JM, de Damborenea J. Microstructure and sliding wear behavior of Tribaloy T-800 coatings deposited by laser cladding. Wear. 2006;260:838-46. http://dx.doi. org/10.1016/j.wear.2005.04.020. 